\title{
FROM GABII AND GORDION TO ERETRIA AND METHONE: THE RISE OF THE GREEK ALPHABET*
}

\section{RICHARD JANKO}

The discovery of numerous inscriptions in a sealed archaeological deposit at Methone in Pieria that is securely dated to the last decades of the eighth century BC is no less a cause for celebration than their rapid and careful publication in a full and well-illustrated edition. This new and very unexpected material sheds light on the diffusion of Euboean writing, on the different stages in the evolution of the Hellenic alphabet, and on when Greek poetry began to be written down. Inscriptions from $730 \mathrm{BC}$ or earlier are now known from a number of coastal sites in the central and eastern Mediterranean, ranging from Pithecussae on Ischia off the west coast of Italy all the way to Methone in Macedonia. Even earlier inscriptions in varieties of the earliest true alphabet come from Lefkandi and Eretria in Euboea, dating by the traditional chronology to 775-750 BC, and from two places just beyond the fringes of the Greek-speaking world, Gordion in Phrygia and Gabii near Rome, where there is an inscription dated according to that chronology to c.770. However, as we shall see, the absolute chronology of the Iron Age is controversial, and the date of this inscription may need to be raised to $c .825$ at the latest.

\section{$\S 1$. The alphabet and dialect of the long inscriptions from Methone}

As the editors note, it is wonderful to see Plutarch's story ${ }^{1}$ about the foundation of Methone by Eretrian settlers confirmed, at least in outline, by the date of the pottery that has been found there, and with it the traditional date of $733 / 2 \mathrm{BC}$ for the foundation of Syracuse. ${ }^{2}$ But are the new inscriptions from Methone written in a range of different alphabets, the origins of which are correlated with the wide geographical range of the place of manufacture of the vessels on which they are inscribed, as the editors suggest, or is their nature more specifically localized? Since most of these alphabetic inscriptions consist of isolated signs, I shall focus on the longest, which offer better prospects of analysis. For convenience, unless otherwise indicated, I shall show the shapes of the

\footnotetext{
* I wish to thank audiences in Thessaloniki in June 2012, at the conference to celebrate the publication of the inscriptions from Methone, and at the Institute of Classical Studies in London, where I presented this topic as the J. P. Barron Lecture in June 2014, for furthering my thoughts on this topic. I am grateful to Yannis Z. Tzifopoulos for his gracious invitation to his conference, the proceedings of which I now learn are to be published, and to Matthew Newman and David Tandy for commenting on drafts of this article. Responsibility for errors remains mine alone.

${ }^{1}$ Plut. Mor. 293 A-B.

${ }^{2}$ Tzifopoulos in Besios, Tsifopoulos, and Kotsonas 2012, 19-20.
} 


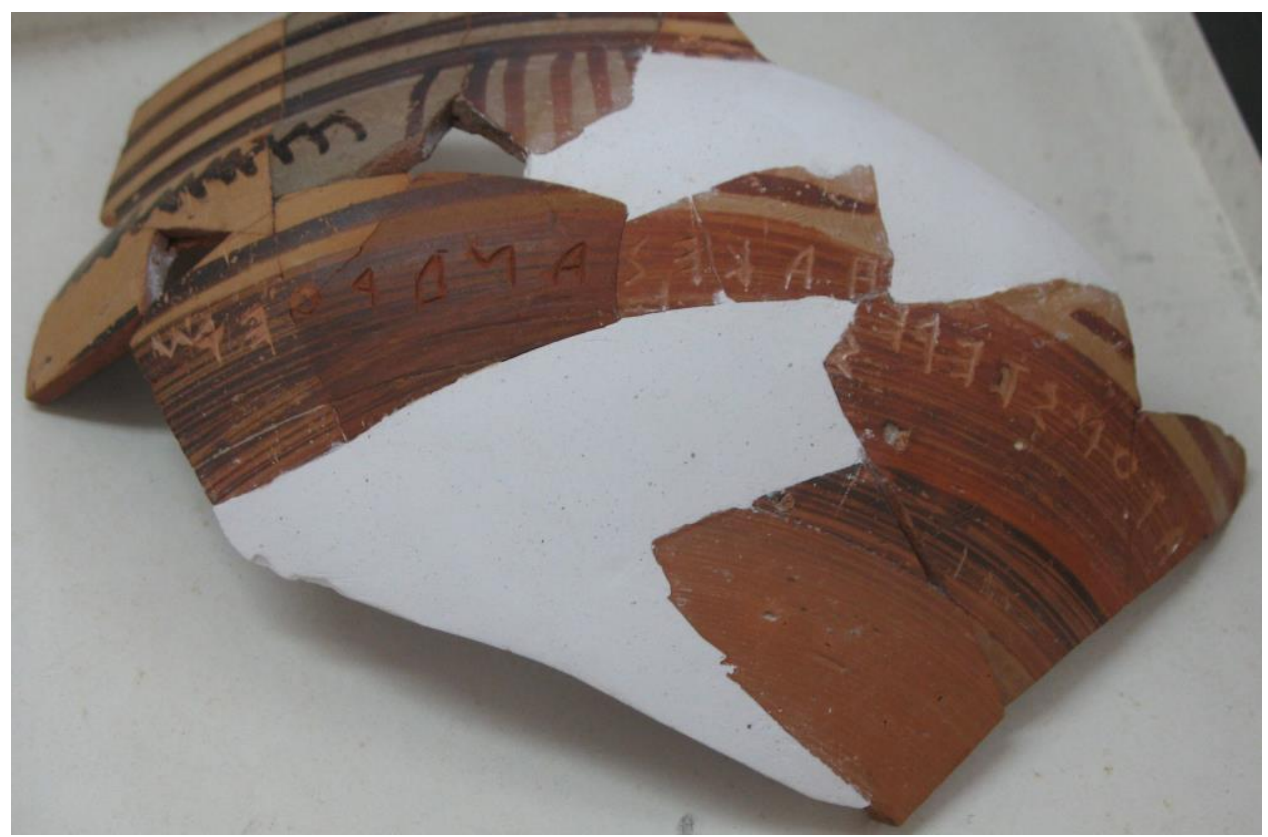

Figure 1. Methone inscription no. 2, the cup of Acesander (photo by M. Hannoosh)

letters in the forms in which they would appear when written from left to right (Phoenician forms are unaltered, i.e. facing from right to left).

The writing of inscription no. 2 (Figure 1), the 'cup of $(\mathrm{H})$ Acesander' which is of Euboean manufacture, is definitely in the script of Eretria in Euboea, since it uses a mu with five strokes, ${ }^{w}$, rather than four, where the final diagonal is dropped. Jeffery ${ }^{3}$ linked the five-stroked mu, which also appears on the 'cup of Nestor' from Pithecussae, specifically with Eretria rather than with Chalcis, which normally has a mu with only four strokes. ${ }^{4}$ The latter mu is a modification, since the Eretrian five-stroked mu is the same as the original West Semitic form. Although Nestor's cup is in the Eretrian rather than the Chalcidian alphabet, ${ }^{5}$ both forms of mu are known in the early inscriptions from Pithecussae, ${ }^{6}$ which accords with Strabo's report that Eretrians and Chalcidians founded it jointly. ${ }^{7}$ The form of delta, rounded above but with an angle at the base, is known at Eretria and Pithecussae, whereas rounded delta $D$ is characteristic of Chalcis and Boeotia. ${ }^{8}$

\footnotetext{
${ }^{3} 1990$ [1961], 81-82.
}

${ }^{4}$ Johnston noted that a later variant of the five-stroked mu is attested at Rhegium, a colony of Chalcis (1990, 455 ); it is also at Himera, a colony of Chalcis, in IGDS ii. 15, a law of c.500 BC.

${ }^{5}$ So Walker (2004, 147), opposing Ridgway (1992, 55 with Fig. 9).

${ }^{6}$ Bartoněk and Buchner 1995, 182, with the table on 184.

${ }^{7}$ Strabo 5. 4. 9. Jeffery doubted the importance of Eretria's early role in the central Mediterranean (1976, 63-64), incorrectly as it now seems.

${ }^{8}$ Jeffery 1990 [1961], 79, where it is her type 3. It is hard to see in the published drawing and plates, but perfectly clear on the original. 
The form of alpha curved at the right $(\mathrm{A})$, normal in Boeotian, is rare in Euboea but does occur at Eretria. ${ }^{9}$

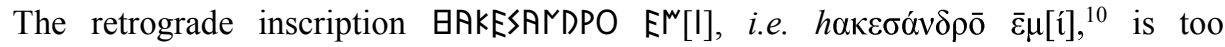
incomplete to give us much precision as to its dialect. However, the initial aspiration of the owner's name guarantees that this text was not written by an East or Central Ionian, since these dialects had psilosis. Hence it is most probably in a West Ionic dialect, i.e. Euboean. I agree with its editores principes that the text concluded with a threat in verse, ending with the iambic clausula $-\mu] \alpha ́ \tau \omega \nu ~ \sigma \tau \varepsilon \rho \eta ́ \sigma[\varepsilon \tau] \alpha \underline{1}$, i.e. $\times-] \cup-\mid \cup-\smile-$ (it is safe to restore the $\mu$ ). We cannot say whether the target of this threat risked losing his eyes

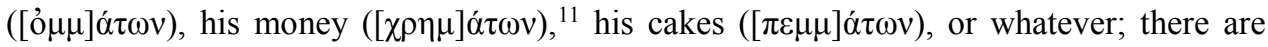
many possibilities. If Acesander was a doctor - his name means 'healer of men', and such professions were often hereditary - it is even possible that Acesander administered medicine in his cup, and promises to the person who drinks from it that he will lose his pains $([\pi \eta \mu] \alpha ́ \tau \omega v)$. The new inscription is another example of the kind of joke that was already known from the 'cup of Nestor', as well as the cup from Eretria published by Johnston and Andriomenou, ${ }^{12}$ which may be that of Euthymus. ${ }^{13}$ One of the earliest attested uses of the Eretrian alphabet was evidently for frivolous verses, threatening punishment for misbehaviour, that were scratched on such vessels at feasts. This supports the theory that the symposium was a major locus for the early use and the transmission of the alphabet. ${ }^{14}$

Two inscriptions are incised on vessels of Lesbian manufacture. Inscription no. 1 (Figure

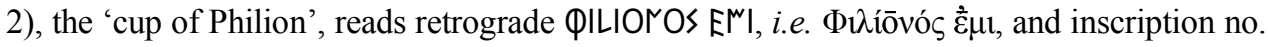
4 , the amphora of Anticydes, made in the gulf of Kalloni, ${ }^{15}$ bears written from left to right

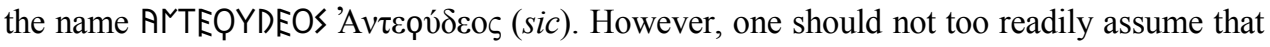
these texts were written by natives of Lesbos. On the amphora the rounded delta $D$ is the common Euboean form, but this is also found on two early inscriptions from Larisa in Aeolis. ${ }^{16}$ On the cup of Philion the upright lambda $L$ is the Euboean, Attic or Boeotian

\footnotetext{
${ }^{9}$ Jeffery 1990 [1961], 79, type 3.

${ }^{10}$ Beekes 2010 s.v. links this aspirate with the Mycenaean word a-ke-te-re which he reconstructs as /hakestēres/ 'healers' on Knossos tablet V 118; it is written with the special sign $a_{2}$ that indicates an initial aspirate, or else with $j a$ - that seems sometimes to have had the same function. However, this word is to be taken as /asketēres/ and describes bronze-smiths. See further Skelton (forthcoming in Tzifopoulos and Clay).

${ }^{11}$ Besios, Tsifopoulos and Kotsonas 2011, 342.

12 Johnston and Andriomenou 1989 (Museum of Eretria no. 10697); Johnston 1990, 434 with pl. 73 (4); Bartoněk and Buchner 1995, 190-2 with Abb. B 1.

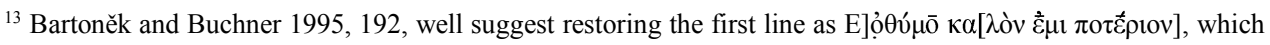

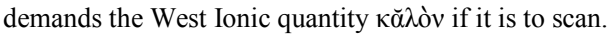

${ }^{14}$ See now the fine study of M. Wẹcowski (forthcoming in Tzifopoulos and Clay).

${ }^{15}$ Kotsonas (forthcoming in Tzifopoulos and Clay).

${ }^{16}$ Jeffery 1990 [1961], 79 (type 1), 359.
} 


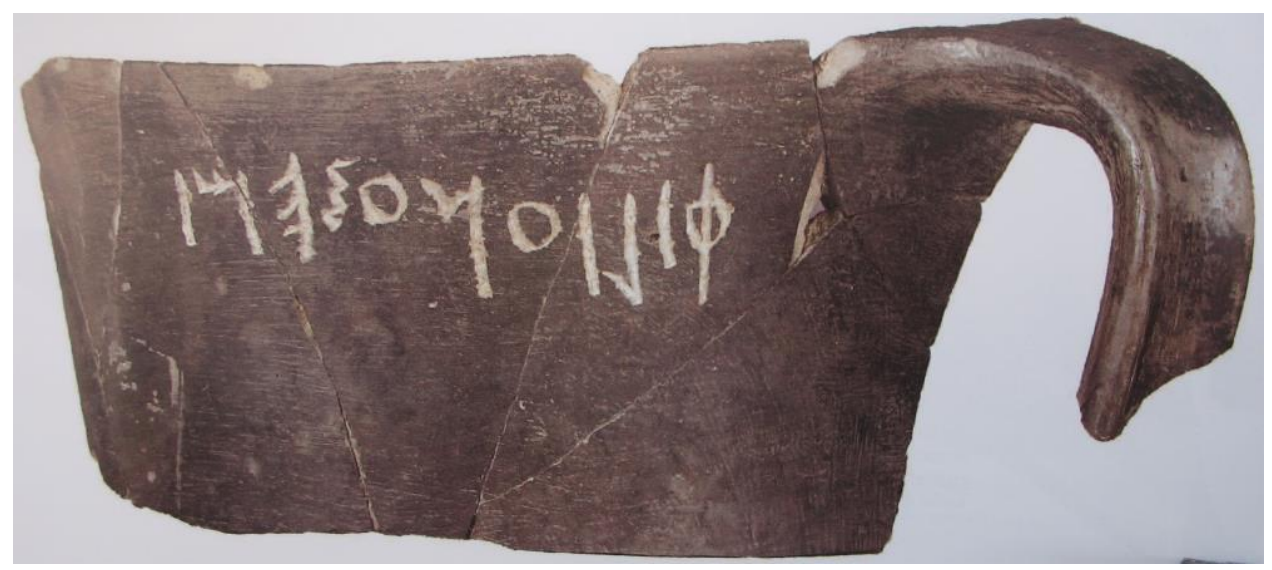

Figure 2. Methone inscription no. 1, the cup of Philion (photo by author)

form, which also occurs in north-central Crete and is the same as the original West Semitic model; but Aeolis uses the inverted lambda $\left\ulcorner.{ }^{17}\right.$ The five-stroked mu ${ }^{\mathrm{N}}$ is typical of Eretria, whereas inscriptions from Aeolis have the four-stroked mu. ${ }^{18}$ Note the small omicron hanging from the upper line,${ }^{19}$ and how tall the letters are.

The very striking six-barred sigma 3 , in which the uppermost and lowest bars point towards the start of the text, is at first sight highly anomalous. However, it recurs at Methone in the retrograde inscription no. 22 (Figure 3), 3XEMI, i.e. (probably) $\sigma \chi \varepsilon v 1$. Euboean scripts normally use a three-barred sigma $\zeta$; a four-barred sigma $\Sigma$ is also known, and the same variation prevails in Aeolis. However, a five-barred sigma also appears in recent finds of late eighth century sherds from Eretria ${ }^{20}$ and Lefkandi, where there are Late Geometric I examples in retrograde inscriptions. ${ }^{21}$ The five-barred sigma, which is the longest version of the 'long' sigma that was previously known, had a wide distribution elsewhere. ${ }^{22}$ It was normal in Laconia and occasionally in the eastern Argolid. It appears twice in Attic inscriptions of c.700 BC, ${ }^{23}$ and once, alongside four-barred sigmas, on the Mantiklosinscription from Thebes of $c .700$. The letter also appears at Kommos in inscription no. 43,

\footnotetext{
${ }^{17}$ Jeffery 1990 [1961], 360-1 no. 3 (Mytilene, late seventh century).

${ }^{18}$ Jeffery 1990 [1961], 360-1 nos. 3 and 8 (Neandria, sixth century at latest).

${ }^{19}$ This omicron 'hanging' from the upper line of writing is paralleled in Jeffery's pl. 73 no. 5, again from Eretria and of the same date.

20 Jeffery 1990 [1961], 79, type 4; Johnston 1990, 433-4, on Euboea nos. 24a, A, and B; cf. also the Late

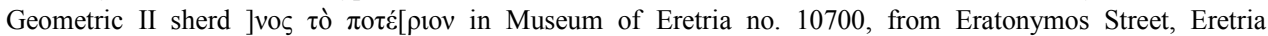
(Andriomenou 1981-82, 235 with fig. 102).

${ }^{21}$ No. 101 in Jeffery 1979, 89-90 with Plate 69b; Bartoněk and Buchner 1995, 196. This is to be restored Aí $\chi p$ í[ovos]. The same parallel was adduced by Méndez Dosuna (forthcoming in Tzifopoulos and Clay). Powell 1991, 123 fig. 1, mistakenly draws a four-barred sigma.

22 Jeffery 1979, 91-92.

${ }^{23}$ Jeffery 1982, 828.
} 


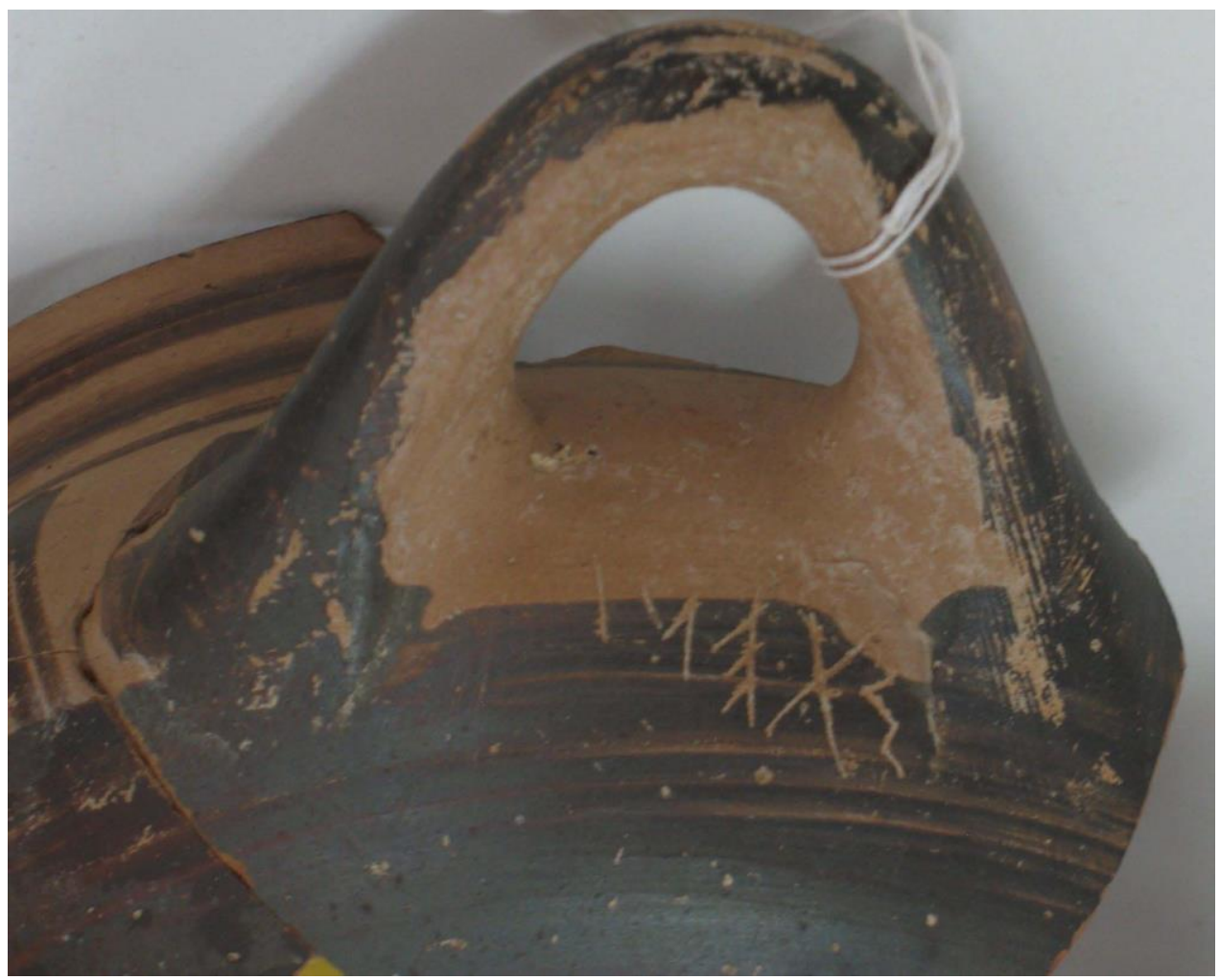

Figure 3. Methone inscription no. 22, XXENI (photo M. Hannoosh)

incised before firing, ${ }^{24}$ and in an incised dedication dated to around 600 from the Samian Heraion. ${ }^{25}$ It also appears in the script of southern Etruria, at Caere (Cerveteri) and Veii, ${ }^{26}$ and in Sabine inscriptions. ${ }^{27}$ However, we must not forget the painted inscription on a dinos from Smyrna, which gives the vase-painter's name as Istrocles and is dated to about $650 \mathrm{BC}$, and another on a fragmentary greave, if not an earlier piece was well. ${ }^{28}$ The two sigmas on the dinos have been compared with Laconian five-barred sigmas, ${ }^{29}$ but both sigmas clearly have six bars. ${ }^{30}$ The script of Smyrna has a four-stroked mu and inverted lambda $\Gamma$, as one would expect in Ionia. There is a seven-barred sigma on a sherd of $c .700$

${ }^{24}$ See Csapo et al. 2000; Oikonomaki (forthcoming in Tzifopoulos and Clay).

${ }^{25}$ Jeffery 1979, 92.

${ }^{26}$ Bonfante and Bonfante 2002, 76 fig. 6.

${ }^{27}$ e.g. Sabini (?) / SABINI 1 (from Chiusi), 625-600 BC, and Capenates (?) / CAPENA (?) 2, c.400 BC, in Crawford 2011, i. 157-58, 173.

${ }^{28}$ Jeffery $1982,830$.

${ }^{29}$ Jeffery 1990 [1961], 341, Ionian Decapolis no. 68a, = pl. 79 no. 8.

${ }^{30}$ Powell 1991, 141, where he illustrates another possible six-barred sigma from Smyrna of $c .700$; $c f$. dell'Oro (forthcoming in Tzifopoulos and Clay). 


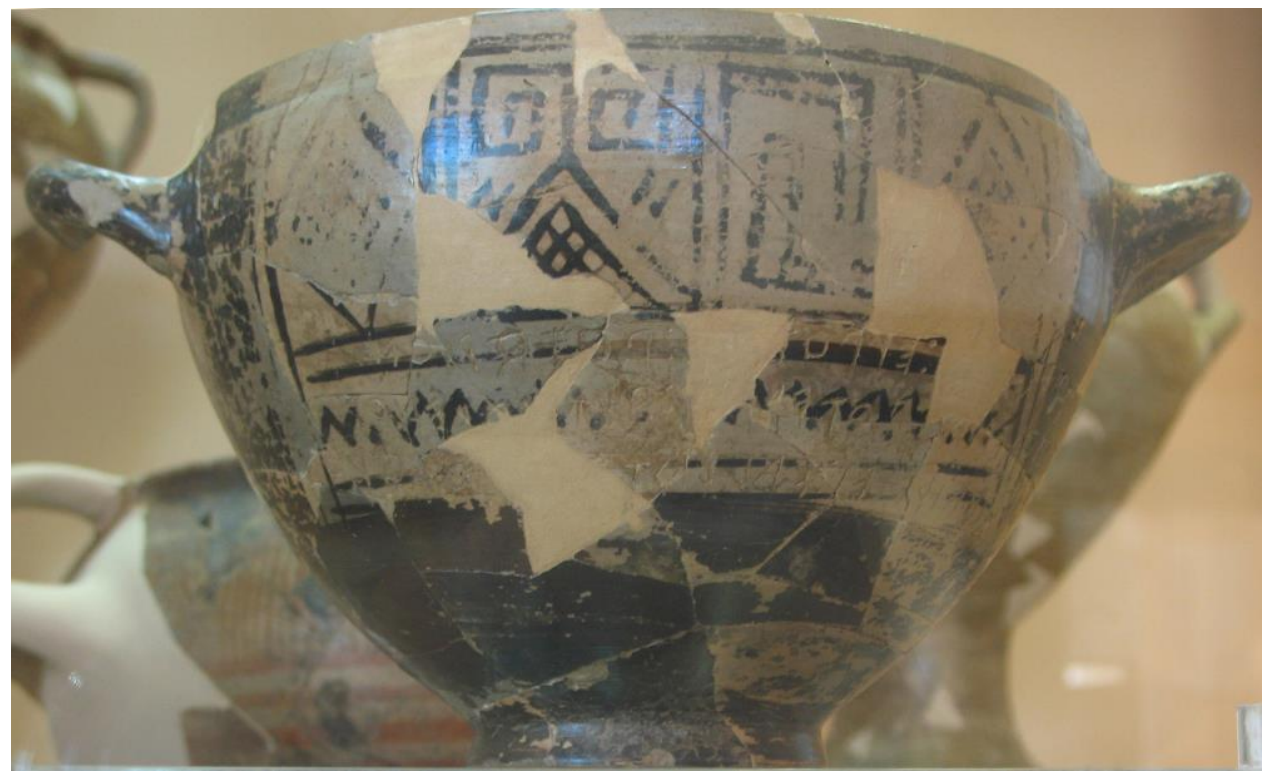

Figure 4. Pithecussae, cup of Nestor (photo by author)

from Eretria. ${ }^{31}$ The six-barred sigma is also found as a variant in early Phrygian inscriptions, to be discussed below ( $\$ 3$ ), beside sigmas with three, five and seven bars, and seven- or eight-barred sigmas appear beside five-barred versions in Sabine. ${ }^{32}$ The earliest stone inscription from the Athenian acropolis, rightly thought to be eighth century, even has a sigma with ten bars. ${ }^{33}$ Thus the 'long' sigma was more widely distributed and earlier than was thought. Since the West Semitic model šin W had four bars, the 'long' sigma was an innovative variant in some of the earliest Greek alphabets.

As for the dialect of these inscriptions, the genitive of 'Anticydes' is the same in both Lesbian and Euboean. However, on the cup of Philion the form $\dot{\varepsilon} \mu \mathrm{t}$ rather than $\varepsilon \mu \mu \mathrm{u}$ is not Lesbian, unless we take the $\mathrm{M}$ to be a single writing of the double consonant; rather, it is compatible with Euboean dialect, where ei $\mu$, the product of compensatory lengthening after the loss of the sibilant in the inherited form ${ }^{*} \dot{\varepsilon} \sigma \mu \mathrm{u}$, is consistently written $\varepsilon \mu \mathrm{t}$. The distinctive features of its script suggest a very early date; as the editors remark, ${ }^{34}$ it is perhaps the oldest inscription from Methone. It may contain the first attestation of the letter phi, which next appears on the 'cup of Nestor' (Figure 4). ${ }^{35}$ Philion, if he was the writer, was surely an Eretrian who happened to acquire a cup from Lesbos and used the six-barred sigma.

\footnotetext{
${ }^{31}$ Johnston 1990, 433-34, Euboea no. A, pl. 79 (5); Bartoněk and Buchner 1995, 193 with Abb. B 4.

${ }^{32}$ See Sabini (?) / [CAERE 1], 575-525 BC, in Crawford 2011, i. 153-54.

${ }^{33} I G \mathrm{I}^{3} 1418$ (E.M. 5365); Johnston 1990, 69-70.

34 Tsifopoulos 2012, 307.

${ }^{35}$ However, phi is also seen at Pithecussae on the amphora from Tomb 575 of c. 740 (Buchner 1978; Bartoněk and Buchner 1995, 171 no. 31; Coldstream 2003, 293). The inscription to be read ]AY PY SQOP[PA on a local cup imitating Protocorinthian (Bartoněk and Buchner 1995, 156 no. 3) is presumably somewhat later.
} 
Thus there is reason to hold that the three longest inscriptions from Methone were all written by Eretrians or by persons using the Eretrian alphabet. If there were Panhellenes at Methone, ${ }^{36}$ the inscriptions prove them to have been present only in the earliest sense of

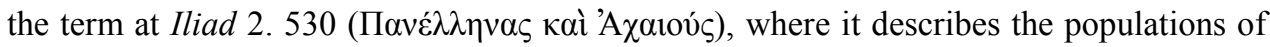
central Greece whom Locrian Ajax can dominate. ${ }^{37}$

\section{§ 2. The earliest Greek alphabet: 'Cretan' script}

Despite Woodard's ingenious theory that the alphabet arose on Cyprus, ${ }^{38}$ and the more convincing one of Powell and Ruijgh that it was a Euboean invention, ${ }^{39}$ internal evidence still suggests that the most primitive form of the Greek alphabet in terms of letter-forms is the version of it that was used on Crete, although it need not follow that it was invented there. Since much the same alphabet was used on Thera and Melos, for convenience I shall in this paper call the script of Crete, Thera and Melos 'Cretan'.

Alone among Greek scripts, 'Cretan' sometimes preserves the forms of beta 9 and eta a from the West Semitic script; the next closest is Corinthian, which must have adapted 'Cretan' script at a very early stage. ${ }^{40}$ Other West Semitic forms are found in both 'Cretan' and Euboean. Thus the Phoenician shape L, the origin of upright lambda $L$, is used at Knossos and other places in Crete; as it survives in Euboean, Attic, and Boeotian, it was a feature of the earliest Greek alphabets. ${ }^{41}$ The 'Cretan' five-stroked mu ${ }^{\alpha}$ ' is the same as the West Semitic form; it continues into Eretrian script, as we have seen. Cretan tends to use kappa plus san KM for $k s$, and xi in any form is not used in early inscriptions there; this suggests that xi was a 'dead' letter that was not used even though it persisted in abecedaria. At Lyttos, however, the Phoenician form of samek 1 was used for $t^{s}$ in the

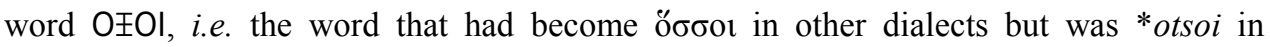
Cretan, ${ }^{42}$ and on Thera it is used for the initial letter of Zzv́ $\varsigma$ (which must nonetheless have been pronounced Dzeus) ${ }^{43}$ this matches the fact that zeta was used on Crete at Dreros, Lyttos and Gortyn for $t^{s},{ }^{44}$ and on Thera and Melos $\Psi$ was used for $k s .{ }^{45}$ Since the Eretrian, ${ }^{46}$ Sabine, ${ }^{47}$ and Etruscan form of xi $⿴ 囗 十$ with closed sides is an innovation for

\footnotetext{
${ }^{36}$ So Besios, Kotsonas and Tsifopoulos 2012, 236, 322.

37 The term Panhellenes comes to denote all the Greeks only after Homer's time, as in Hesiod, Erga 528

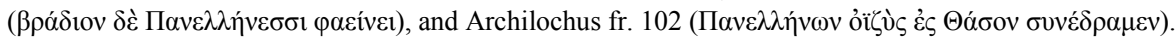

${ }^{38}$ Woodard 1997.

${ }^{39}$ Powell 1991; Ruijgh 1995, 26-47; id. 1997; id. 1998; id. 2011, 260-61.

${ }^{40}$ Jeffery 1990 [1961], 23.

${ }^{41}$ Jeffery 1990 [1961], 30.

42 Duhoux 1982, 164-66, who notes that the word also appears at Lyttos with zeta, i.e. OIOI.

${ }^{43}$ Jeffery 1990 [1961], 317; Powell 1991, 130. The canonical zeta I is unknown there (Jeffery 1990 [1961], 317).

44 Jeffery 1990 [1961], 316; Buck, C.D. 1955, 70.

45 Jeffery 1990 [1961], 308-9; Duhoux 1982, 165.

${ }^{46}$ The form is now known from an abecedarium from the sanctuary of Apollo at Eretria (Kenzelmann Pfyffer $e t$ al. 2005, 60 no. 3); see Table 1 .
} 
Phoenician samek $\mathrm{x}$ with only one central upright, and is not found in other alphabets, it follows that the Eretrian alphabet, at least in the first form in which it is known, was not the earliest version of Greek alphabet.

A further proof of the antiquity of 'Cretan' script is provided by its use of the crooked iota 3 , resembling West Semitic 7 yō $d$ but without its crossbar, rather than the straight iota I used in Euboea and elsewhere, which is not Phoenician. (The only possible parallel in Phoenician for the straight iota is in the Proto-Canaanite left-to-right alphabet of perhaps c. $1100 \mathrm{BC}$ from 'Izbet Șarțah in northern Israel, where $y \bar{o} d$ would appear retrograde as $y,{ }^{48}$ but this is far too early.) The script of Corinth (and of some places near Corinth or dependent on it) likewise employs crooked iota, which is also seen on the Late Geometric Ib Dipylon oenochoe from Athens. Now 'Cretan' script uses four-barred sigma $\Sigma$ like the West Semitic šin W; this was readily distinguishable from the crooked iota 3 . The latter must have been replaced with the upright bar I when sigma became the Euboean form $>$ rather than $\Sigma$. It is surely relevant here that 'Cretan' script, unlike most early Greek scripts, uses an upright hasta as word-divider, ${ }^{49}$ Phoenician writing uses such uprights, whereas the earliest Aramaic inscription, that from Tell Fakhariya in northern Syria, dated to $c .830$, uses two vertical dots, or occasionally three. ${ }^{50}$ Three vertical dots are attested as punctuation in Euboean and many other early scripts, including Phrygian, Latin, ${ }^{51}$ Sabine, ${ }^{52}$ Etruscan, ${ }^{53}$ and the script used to write a form of Etruscan on Lemnos in the later sixth century BC. ${ }^{54}$ Hence I suggest that the vertical word-divider was the origin of the upright iota I.

Previous studies of early alphabetic epigraphy, which needs to expand its horizons to include these other languages, seem not to have taken the word-divider into account when considering how letter-forms evolve. The use of the vertical bar must have been connected

${ }^{47}$ Crawford 2011, i. 9, who accepts that in Sabine it was assigned the value $i$, presumably because it was available as a dead letter in the abecedarium.

${ }^{48}$ Kochavi 1977. The abecedarium is line 5; the language of lines 1-4 is unidentified, but might well be Philistine.

49 Jeffery 1990 [1961], 308-9; see now the Theran house-model, c.650-625, A in Johnston 1990, 470 with pl. 79.4-5. This divider is also known at Sicyon near Corinth, while Laconia uses a curved line (ibid. 138, 183-84).

${ }^{50}$ See Sass 2005 , 40-43 with fig. 13 , who dates it to the ninth century, perhaps the 840 s to 820 s; so too Whisenant 2008, 155-6 n. 505.

${ }^{51}$ On the Praenestine fibula words are separated by two vertical dots, but the first syllable of FEE:FERKED fefaked, i.e. 'fecit', is separated by three. This is, I suggest, an instance of the 'syllabic writing' known at Veii from c.600 and in Venetic ( $c f$. Wallace 2008, 26). The authenticity of this controversial inscription has been upheld by the recent scientific analysis of Edilberto Formigli and Daniela Ferro of the Department of Physics at La Sapienza: see http:/www.anteamurlo.it/. Its letter-forms continue to look correct as our knowledge increases. The Lapis Niger from the Forum uses three vertical dots as word-separators.

52 e.g. Sabini (?) (Caere 1), 575-525 BC, in Crawford 2011, i. 153-54.

${ }^{53}$ Wallace 2008, 25.

${ }^{54}$ Bonfante and Bonfante 2002, 60-2 with fig. 4 (two or three dots); Wallace 2008, 218-21 with fig. 12.1. For more details see Heurgon 1980 and 1982. That Etruscans had settled on Lemnos is recorded in traditions about Pythagoras: so Aristoxenus in his Life of Pythagoras (fr. 11 Wehrli, in D.L. 8.1 and Clem. Alex. Strom. 1. 62); Neanthes, active in c.200 BC, in book 5 of his Mythika (FGrH 84 F 29, in Iambl. Vit. Pythag. 2); and Antonius Diogenes' Wonders beyond Thule, cited by Porphyry, Vit. Pythag. 10-13. Their script is so divergent from standard Etruscan that they must have been cut off from their homeland for a long time. 
with that of the crooked iota, since there would otherwise be confusion about the meaning of the upright bar. Its replacement by the vertical dots surely derives from Aramaic. Sass ${ }^{55}$ rejects the suggestion that the Greek and Phrygian word dividers derive from Aramaic, ${ }^{56}$ on the ground that only Phoenician writing was known in Anatolia in the eighth century, but this neglects the evidence from Italy and begs the question of the origin of Phrygian script. Ruijgh $^{57}$ proves that the letter-names were borrowed from Phoenician, since Phoenician rôs 'head' is clearly the origin of $\hat{\rho} \hat{\omega}$, rather than from Aramaic, where the letter-name is rêš; but this does not prove that there was no Aramaic influence on the development of the script.

The Etrusco-Latin alphabet exhibits one other form that derives from the earliest Aramaic script. In arguing that the Greek alphabet was created in c.1000 BC, Ruijgh pointed to the early form of the West Semitic letter 'ayin. ${ }^{58}$ There was originally a dot, representing the pupil, in the centre of West Semitic 'ayin, 'eye', which is still seen on the Proto-Canaanite inscriptions of c. 1100 BC from 'Izbet Șarțah in northern Israel ${ }^{59}$ and of c.925-900 (the transition from Protogeometric to Geometric) on the bowl from Tekke near Knossos. This form is standard on the earliest Aramaic inscription from Tell Fakhariyah of $c .830 ;{ }^{60}$ however, it is not found in ninth- or eighth-century Phoenician texts. The dotted omicron $\odot$ appears in 'Cretan' script at Lyttos and on Thera, ${ }^{61}$ in a possible inscription consisting only of $\odot$ [, Middle Geometric II in date, from the temple of Apollo Daphnephoros at Eretria, ${ }^{62}$ in an inscription painted before firing on the foot of a krater

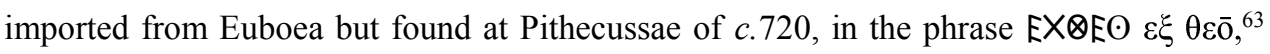
and in inscription no. 5 from Methone $(\otimes E \odot \theta \varepsilon \overline{0})$; it is not on Nestor's cup. This dotted omicron is used to mark lengthened /o/, rather like later $\Omega$; Jeffery's classification of it as a kind of omega ${ }^{64}$ has obscured its importance. Dotted omicron is present in the model alphabets from Etruria found at Marsiliana d'Albegna, Formello near Veii and Sorbo near Caere, ${ }^{65}$ and in the script used on Lemnos to write a form of Etruscan. ${ }^{66}$ The seventh-

\footnotetext{
${ }^{55}$ Sass 2005, 139 n. 228.

${ }^{56}$ So Bordreuil 1993, 263.

${ }^{57}$ Ruijgh 1995, 27 n. 68.

${ }^{58}$ Ruijgh 1995, 40-43.

${ }^{59}$ Kochavi 1977.

${ }^{60}$ Sass 2005, 42 fig. 13.

${ }^{61}$ Ruijgh 1995, 42. For Crete, $c f$. Johnston 1990, 468 no. 14b, pl. 79 (1), the mitra of Spensitheos from Arkades, c.500. For early Theraean examples see Powell 1991, 142 = Jeffery 1990 [1961], 317, 319, pl. 61 (3.ii); Powell

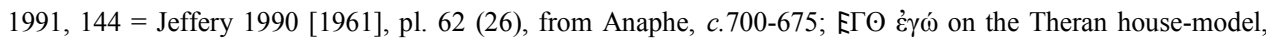
c.650-625, in Johnston 1990, 470 with pl. 79 (4-5).

${ }^{62}$ Kenzelmann Pfyffer et al. 2005, 66 no. 26.

${ }^{63}$ Bartoněk and Buchner 1995, 178.

${ }^{64}$ Jeffery 1990 [1961] 309. Johnston deems it a development of the received shape O, and denies that it is present in the earlier material $(1990,426)$.

${ }^{65}$ Bonfante and Bonfante 2002, 131-33 with figs. 12-13.

${ }^{66}$ Bonfante and Bonfante 2002, 60-62 with fig. 4; Wallace 2008, 218-21 with fig. 12.1. In inscription A both O and $\odot$ occur rather than the expected Etruscan letter Y (inscription B has only O).
} 
century Latin inscription from Gabii $\Sigma$ ALYET@DTITA, i.e. salvetōd Tita, has it, ${ }^{67}$ although it is not used in $\mathrm{E}\left(\mathrm{O}\right.$, i.e. eg $\bar{o}$, in the equally old inscription of Vendia. ${ }^{68}$ Perhaps the 'Cretan' script introduced an Aramaic variant in order to distinguish short $o$ from long $\bar{o}$, but did not formally add it to the abecedarium. Conversely, in a clear misunderstanding of the convention, an inscription from Tanagra uses two dotted omicrons for short omicron

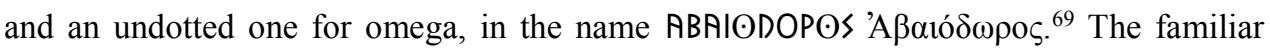
alternative, the supplemental letter omega $\Omega$, was added to the end of the Ionian alphabet by $c .650 \mathrm{BC}$ at the latest, when it appears on Samos. ${ }^{70}$

All the Greek scripts use Phoenician variant forms to divide Semitic $w \bar{a} w$ into digamma $\mathrm{F}$ and hypsilon $\mathrm{Y}$, with hypsilon added on to the alphabet after the last Semitic letter $t \bar{a} w .^{71}$ It has been suggested that similar variants provided the basis for dividing qōph $\Phi$ into qoppa $\mathrm{Q}$ and phi $\Phi, t \bar{a} w / \rho$ into tau $\mathrm{T}$ and chi $\mathrm{X}$, and kaph $Y$ into kappa $\mathrm{K}$ and psi $\Psi .{ }^{72}$ The invention of hypsilon was the decisive innovation that separates Greek from Phoenician script. (Thus, if we could accept the authenticity of the bronze tablets in the Schøyen collection, reported to have been found in the Fayum in Egypt, which bear an alphabet that ends with the letter $t \bar{a} w /$ tau and is written out from right to left many times in scriptio continua, this alphabet would be Phoenician, not Greek. ${ }^{73}$ However, the mixture of ancient and more recent shapes raises serious doubts as to whether these tablets are authentic. ${ }^{74}$ )

Lastly, the Dipylon vase from Athens preserves not only crooked iota but also another archaic shape, the West Semitic sideways alpha, which is found in hardly any other Greek

${ }^{67}$ Colonna 1980. The O, incomplete at the top, has a diagonal in the lower right that crosses the arc, rather like Q.

${ }^{68}$ Baldi 2002, 126 (the inscription contains no short $o$ ).

${ }^{69} I G$ VII 612, cited by Bartoněk and Buchner 1995, 178.

${ }^{70}$ Johnston 1990, 428; this is earlier than the instance at Smyrna of c.625, cited as oldest by Coldstream 2003, 278.

${ }^{71}$ Heubeck 1986, 17. The seventh-century law from Dreros (BCH 61 (1937) 333-38 and 62 (1938) 194-5= Jeffery 1990 [1961], 311 no. 1, pl. 59) uses the digamma both for the consonant $w$ and for the second element of

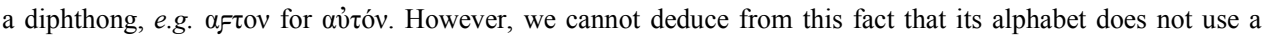
separate hypsilon, since nowhere in it does the phoneme $/ u$ / occur between two consonants (I thank Rudolph Wachter for this point).

72 See Jeffery 1990 [1961], 36, for references (so too Heubeck 1986, 17). Ruijgh (1997, 667-68) suggests that the first two supplemental letters were $\Phi$ and $*$, back-to-back versions of the early forms of $\Pi$ (originally rounded) and $K$, and that $X$ and $\Psi$ were created from $*$. See also Powell 1991, 49 n. 142, who proposes $(1991,58)$ that the original value of psi $\Psi$ was $*$ $h$ (i.e. an aspirate corresponding to qoppa).

${ }^{73}$ Pace Woodard 1997, 157, who thinks they are Greek. The tablets are published in Scott et al. 2005 (mainly technical studies, with no good epigraphic commentary); another tablet from the same set is in Würzburg (see Heubeck 1986).

74 The script is close to that of Euboea, except that the lambda $\Gamma$ is inverted, and of Crete (but it includes sigma); it differs from Phoenician script in that it has inverted lambda $\Gamma$, Eretrian $\mathbb{t}$ xi with closed sides rather than open 玉, qoppa $Q$ where the upright does not cross the circle, and upright four-barred sigma $\Sigma$. It fluctuates between eighth-century and later Greek forms: $E$ and $F$ with horizontals as well as diagonals, $Z$ as well as I, and lambda with diagonals one of which sometimes reaches the base-line, as $\Lambda$, and sometimes does not, as $\uparrow$; yet it has crooked iota $\zeta$ and Phoenician șâdê $r$. Heubeck noted the admixture (1986, 14-16). 
text, ${ }^{75}$ including those in 'Cretan' script, unless the alpha of the Schøyen tablets shaped $\Delta$ (here shown left to right) is another. Remarkably, the form appears in two early inscriptions from central Italy, a retrograde graffito $\varangle\lfloor[$ on a cinerary urn from Bologna currently dated $c .800-750,{ }^{76}$ and a retrograde initial abecedarium (but with the letters facing from left to right) $\varangle B+D$ on an amphora with spirals from Veii, dated $c .675-650 .{ }^{77}$ Sidelong alpha is also known at Pithecussae on a late eighth century sherd inscribed in Phoenician $] L \ll{ }^{78}$ Jeffery suspected that the inscriber of the Dipylon vase was not using the script ancestral to what we call Attic script, but rather, perhaps, that he came from the place where the alphabet was first adapted. ${ }^{79}$ However, although his pi $\Gamma$ is rounded like that of Crete and Pithecussae, ${ }^{80}$ which continues the Phoenician model, his lambda $\uparrow$ is inverted, uniquely in early Attic inscriptions. ${ }^{81}$ This inverted lambda is a departure from the Phoenician original, as we have seen. But the presence of the sideways alpha $\varangle$ in central Italy confirms that that region received the alphabet at a very early date indeed.

In short, the internal evidence of the letter-forms and lack of the 'supplemental' signs $\Phi, \mathrm{X}$, and $\Psi$ seem to indicate that the 'Cretan' script is the oldest. This is not entirely certain, however, since in Crete the supplemental signs could have persisted unused, for lack of need, at the end of the original abecedarium, since no early Cretan alphabets are known. ${ }^{82}$ But the fact that phi and chi follow hypsilon at the end of all the other Greek alphabets does suggest that these signs were added, either at the same time as hypsilon or in a subsequent phase of adaptation.

As for when the Greek alphabet was created, Ruijgh argued on linguistic grounds that it was invented in $c .1000 \mathrm{BC} .{ }^{83} \mathrm{He}$ holds that the adoption of Phoenician $h \bar{e}$ with a weak aspirate as epsilon and hèth with an emphatic aspirate as eta shows that the alphabet was adopted before Greek aspirate so weakened as to allow elision as in, e.g., Homeric ' $\dot{\varphi}$ ' $\dot{\alpha} \lambda$ ó $\zeta$ as compared with Mycenaean /opihala/. His linguistic analysis is convincing, but his dating of the Greek sound-change to 1000 rather than, say, 800, is arbitrary; we know only that it occurred between 1200 and Homer's time. Likewise, he suggests that the borrowing of șäde as the letter 'san' reflects the early pronunication of the letter as $t s$ and shows that the alphabet was adapted before the Greek dialects had altered $* t s$ into $t$, ss or other outcomes. Again the linguistic argument is valid, but the dating to $c .1000$ is not, since it is

\footnotetext{
${ }^{75}$ There may be a parallel in the inscriptions from Hymettus of c.700 (Jeffery 1982, 828).

${ }^{76}$ This is from Tomb 21 Benacci-Caprara of villanovan Bologna (Colonna 2005, 479-80 with fig. 3).

${ }^{77}$ Colonna 2003; Colonna 2005, 479-80 with fig. 2.

78 Jeffery 1982, 828; Bartoněk and Buchner 1995, 188 with Abb. A 2; Coldstream thinks it is Greek (2003, 279-80 with Fig. 94).

${ }^{79}$ Jeffery 1990 [1961], 68.

${ }^{80}$ Coldstream 2003, 279-80 with Fig. 94; Jeffery does not note this fact (the pi is her form 1).

${ }^{81}$ Jeffery 1990 [1961], 66.

${ }^{82}$ Jeffery 1990 [1961], 35; Powell 1991, 48-63, esp. 55-57. The use of phi $\Phi$ in Eteocretan $\varphi \rho \alpha 1 \sigma o \varsigma$ for the place-

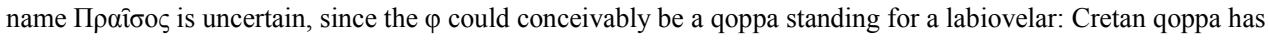
the identical shape $\Phi$, which is the same as the West Semitic model. Duhoux (1982, 172-73) opposes Jeffery's proposal that the letter be read qoppa, and is clearly right in some cases.
}

${ }^{83}$ Ruijgh 1995, 1998. 
clear that $*$ ts persisted in some environments and dialects until well after the eastward expansion of the Ionic dialects that is traditionally dated to $c .1000$. The latter date supplies only a terminus post quem for the adoption of the alphabet.

West Semitic script was known in the Aegean by 900 BC, since late Proto-Canaanite writing, from which Phoenician was then evolving, appears on a bronze bowl dated to the transition from Late Protogeometric to Early Geometric, i.e. c. 900 or a little earlier by the traditional chronology, found at Tekke near Knossos on Crete. ${ }^{84}$ Aramaic inscriptions of King Hazael of Damascus on two pieces of equine bronze armour, dated by Levantine chronologies to $c .830$, were found at the temple of Apollo at Eretria and at the Heraeum on Samos, ${ }^{85}$ but these reached Greece as late eighth-century dedications. ${ }^{86}$ A Phoenician retrograde graffito KPLS $\breve{S}$ has been found at Eretria; it is written on a local Middle Geometric I sherd from a context no later than Middle Geometric II, i.e. c.800-750 BC according to the traditional dating. ${ }^{87}$ Its inscription probably means 'double' ${ }^{88}$ from the root KPL. This interpretation leaves the final $-\check{s}$ is unexplained, but it seems unlikely that

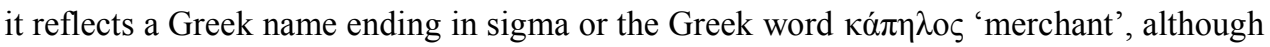
Greek final $-\varsigma$ is normally transliterated into Phoenician as $-\breve{S}^{89}$ The presence of Phoenician writing in Eretria in Middle Geometric II shows that Greek script could even have been invented at Eretria rather than in Crete. Indeed, Popham dated two very fragmentary inscriptions from Lefkandi to local Sub-Protogeometric III (= Middle

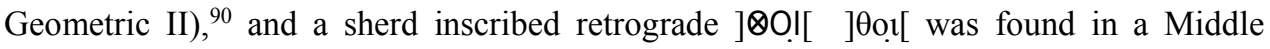
Geometric II level of the sanctuary Apollo Daphnephoros at Eretria. ${ }^{91}$ Since these texts do not include the letter hypsilon, they do not prove that the most decisive innovation, the invention of that vowel-sign, had yet taken place. However, the letter-forms of 'Cretan' script are certainly closest to those of the monumental West Semitic writing of the late ninth and early eighth centuries, ${ }^{92}$ except that the Greek form of $w \bar{a} w F$ is the cursive form, and the monumental Phoenician form $y$ was put at the original end of the alphabet as the hypsilon. The best parallels are the $\mathrm{Ba}^{6} \mathrm{al}$ of Lebanon inscriptions on a set of bronze

\footnotetext{
${ }^{84}$ Sass 2005, 34-36, 153-54.

85 Johnston 1990, 426.

${ }^{86}$ They would have been looted when Tiglath-Pileser III captured Damascus in 733/2 (Lane Fox 2008, 116-18).

${ }^{87}$ Kenzelmann Pfyffer et al., 2005: 76-77, no. 66.

${ }^{88}$ Garbini 1978 reads an inscription on the Levantine amphora from Pithecussae Tomb 575 (Late Geometric I, c.740, according to Buchner 1978, 142) as KPLN in Aramaic, i.e. 'double' in the dual with the correct Aramaic suffix; cf. Hebrew kiplàyim 'double'. For a hybrid Aramaic-Greek interpretation see Bartoněk and Buchner 1995, 187-88; Coldstream 2003, 293. The Semitic texts from Pithecussae are all Late Geometric: for a convenient collection of them see Bartoněk and Buchner 1995, 187-89.

${ }^{89}$ See Schmitz 2009, 125-26, who convincingly suggests that the mace-bearing Storm-god repeatedly named

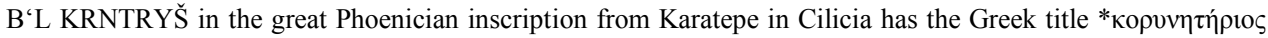

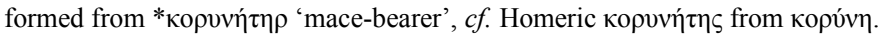

${ }^{90}$ Jeffery 1979, 89-90 (no. 102) and 93, with pl. 69d; Powell 1991, 15 n. 34, where Popham per litt. suggested a date of c.775 BC; Bartoněk and Buchner 1995, 195, where they republish all the early sherds from Lefkandi. The surviving letters of no. 102 are probably retrograde ] $\sigma \alpha$ rather than left to right $\alpha \mu[$. The upright alpha shows that the script is not Phoenician.

${ }^{91}$ Kenzelmann Pfyffer et al. 2005, 75 no. 64.

${ }^{92}$ Isserlin 1982, 816; Sass 2005, 182.
} 
bowls from Qart-hadašt, i.e. Kition (Larnaca) in Cyprus, which are now in the Louvre and are dated on palaeographical grounds to the first half of the eighth century. ${ }^{93}$ But such was Phoenician mobility that their find-spot does not necessarily support the theory that the Greek alphabet arose in Cyprus.

\section{§ 3. Gabii, Pithecussae and Iron Age chronology}

The lack of early alphabetic inscriptions from Crete and Cyprus tells against either as the place where the alphabet was adapted. A left-to-right Greek graffito on a Late Geometric II skyphos from c.725-700, reading ]!्ABEỌ[, i.e. ]. $\alpha \beta \varepsilon 0$ [ in an alphabet that may be Euboean, has at last been discovered by the mouth of the Orontes at 'Al Mina', ancient

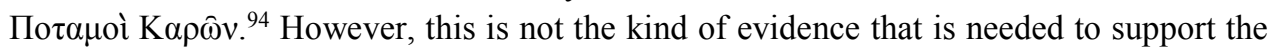
popular theory that the alphabet originated there. ${ }^{95}$ Obviously we have to reckon with the dangers of the argumentum ex silentio which has so often been used to date the Greek alphabet; ${ }^{96}$ but if the finds of inscriptions on durable pottery and bronze reflect the diffusion of alphabetic writing, it originated neither there nor in Crete. If the distribution of finds does reflect at all accurately where and when the alphabet originated, and there was not a long period when the only such writing was on perishable materials, we need precision about the date of these inscriptions.

However, the chronology of the Geometric period has recently become hotly contested; without a resolution of the difficulties, it will be hard to determine where and when the earliest inscriptions appear. The relative chronology of Proto-Geometric and Geometric pottery, based on stylistic sequencing and closed deposits, is not in doubt. However, Coldstream determined the absolute dates of the various phases by reference to finds of Greek pottery in contexts in Israel that others have dated - not without continuing debate - by historical reasoning; these have in their turn been used to determine the absolute dating of archaeological phases in the whole central and western Mediterranean, since Greek pottery can be given more precise stylistic dates than can the indigenous or Levantine wares. However, during the last decade these absolute dates have been called into question by dendrochronology from central Europe combined with new radio-carbon dates from Italy and Carthage. This new chronology, advanced by Nijboer and others, ${ }^{97}$ is based on radiocarbon dates from Francavilla Maritima near Metapontum, Fidenae near Rome, Carthage, Huelva (Tartessus), and Tel Rehov in Israel, applying Bayesian analysis to refine stratified sequences of ${ }^{14} \mathrm{C}$ dates. It strongly suggests that Coldstream's absolute dating of the phases of the Geometric period is too low.

\footnotetext{
${ }^{93}$ See Sass 2005, 134, 144, 182, for a date rather earlier than 750, following Lipiński 2004, 47-48.

94 Johnston 1990, 426, 476; Bartoněk and Buchner 1995, 199 with Abb. B 20; Lane Fox 2008, 105-07, who determines the site's ancient name and shows from Assyrian records that it was founded before 738.

${ }^{95}$ Cf. Young 1969, 294-96; Johnston 1990, 425; Lane Fox 2008, 136; Lemaire 2008, 51-52.

${ }^{96}$ For a vigorous polemic see Ruijgh 1995, 36-39.

${ }^{97}$ For a convenient summaries see Nijboer et al. 2000, 173-74; Nijboer 2005, 527-56, esp. 528 with Tables A-B and 541 with Table D; Nijboer and van der Plicht 2008; van der Plicht et al. 2009. For a vigorous rebuttal see Fantalkin et al. 2011. Toffolo et al. 2013 does not address this part of the chronological sequence,
} 
Under the new schema, Early Geometric I began 25-50 years earlier than the traditional date of c.900 BC, Middle Geometric I some 50-75 years earlier (i.e. c.925-900 rather than c.850), Middle Geometric II similarly (i.e. c.875-850 rather than c.800) and Late Geometric I likewise (i.e. c.825-800 rather than c.750). However, the date of the end of Late Geometric remains much the same; for the chronological uncertainty ends with the Late Geometric II Tomb 325 at Pithecussae, which contained a scarab of Bocchoris, who reigned in 721-716 or 716-711. Hence Early Protocorinthian cannot begin until c.715.

The new chronology lengthens the duration of Late Geometric, extends the period when the Greeks were exploring the central Mediterranean, and allows time for the Phoenicians to settle there in the tenth and ninth centuries before the Greeks' arrival, as Thucydides attests that they did..$^{98}$ Radiocarbon dating supports the traditional date for the Phoenician settlement of Tartessus (Huelva), provided that it is the same place as biblical Tarshish, during the reign of Hiram I of Tyre (mid-10th century $)^{99}$ and the foundation of Carthage of $814 .{ }^{100}$ Since Euboean Late Geometric I pottery from Pithecussae was found in the lowest levels at Carthage, ${ }^{101}$ by the High Chronology Euboeans had settled at Pithecussae before $c .800 .{ }^{102}$

The discovery, in Tomb 482 of the cemetery of Osteria dell'Osa at ancient Gabii near Rome, of a 'Greek' inscription scratched on a local impasto flask dated to Latial IIB2, ${ }^{103}$ i.e. traditionally c.775 $\mathrm{BC}$ and now, according to the new radiocarbon dating, at the latest $c .825,{ }^{104}$ has seemed so isolated in time and space that scholars of Greek and Semitic epigraphy have been reluctant to take it seriously. ${ }^{105}$ Yet it must be genuine. Although the very top of the pit of tomb 482 was cut by the seventh-century tomb 485 , the archaeological evidence shows that the flask cannot have intruded from the later burial; it was found in the pit in a marginal position on the surface of the stones that were used to fill Tomb 482. ${ }^{106}$ If it was used for extinguishing the pyre, a custom known at Pontecagnano, this would explain its find-spot. ${ }^{107}$ The text appears to read from left to

\footnotetext{
${ }^{98}$ Hist. 6. 2. 6.

${ }^{99}$ Nijboer and van der Plicht 2008, 109-13.

${ }^{100}$ Docter et al. 2005. The date is from Timaeus (FGrH $566 \mathrm{~F} \mathrm{60),} \mathrm{who} \mathrm{placed} \mathrm{it} 38$ years before the first Olympiad, but dated the foundation of Rome to the same year. Pompeius Trogus dated it 72 years before the foundation of Rome, i.e. (presumably) $753+72=825 \mathrm{BC}$ (Justin 18. 6), but this date may refer to the earliest Punic base on the island Cothon in the harbour, which predated somewhat the foundation on the mainland (Justin 18. 5). Dido's paternal grandfather Ba'al-'azor (Jos. In Apionem 1. 18, from Menander of Ephesus) is probably the same king of Tyre who paid tribute to Shalmaneser III in 841 (Liver 1953; Peñuela 1953).

${ }^{101}$ Docter et al. 2005, 561.

${ }^{102}$ Demand 2013, 245-46.

103 See Ridgway 1996, who shows that the grave, that of a woman, has features reminiscent of those at Pithecussae.

${ }^{104}$ See Nijboer et al. 2000, 173-74; Nijboer 2004, 527-56, esp. 528 with Tables A-B and 541 with Table D.

105 Thus Sass 2005, 155-56 (with further references), thinks that either the pot is later than the grave or that the writer imitates Phoenician script, which the Latins could have known from contemporary Phoenician settlement on Sardinia.

106 Bartoloni and Nizzo 2005, 411 n. 21; Colonna (2005, 479) and Bietti Sestieri (2005, 486-87) conclusively disprove the suggestion of an intrusion on archaeological grounds.

${ }^{107}$ So Ridgeway 1996, 92 n. 33.
} 
right EYLIN, which is hard to interpret but may mean $\varepsilon v^{2} \lambda \mathrm{vv}(\mathrm{os})$ 'good at spinning', possibly an attribute of the woman with whom it was buried. ${ }^{108}$ However, the lambda faces in the opposite direction. If we read instead from right to left, and disregard the fact that EY and $\Gamma$ then face the wrong way, the reading would be MILYE, which one might interpret as Latin $n i$ lue "do not pay'; 109 however, this approach is harder both linguistically ${ }^{110}$ and because it entails reversing the direction of more letters.

Whatever this text means and whether its language is Latin or Greek, the use of the apparent vowels $\mathrm{E}, \mathrm{Y}$ and I shows that it is not in West Semitic script. It contains hypsilon in its canonical early shape, and the creation of hypsilon is the salient feature of the early alphabet. The upright iota I shows that the inscription from Gabii is not in 'Cretan' script either, but has advanced beyond the crooked iota; yet its ductus is characteristic of very early inscriptions. According to Dionysius of Halicarnassus, Romulus and Remus were sent as children to Gabii to learn Greek letters; ${ }^{111}$ this would have been in around the $770 \mathrm{~s}$ BC. The oldest Latin inscription, EALYET@DTITA, i.e. salvetōd Tita, perhaps of c.670, comes from tomb 115 of the same cemetery. ${ }^{112}$

In this part of Italy, not far from Pithecussae, we would expect to encounter Euboeans rather than Cretans; and since the iota is straight not crooked, the script is probably Euboean. Phoenician, North Syrian and Euboean inscriptions at Pithecussae may go back to the origins of that settlement; Euboeans and Levantines may both have been present from the start. ${ }^{113}$ Could the alphabet have even been created at Pithecussae? ${ }^{114}$ If the new chronology is sustained, the site can no longer be said to have been founded too late for this to be possible. ${ }^{115}$

As has been noted, 'the Etruscan alphabet ... seems to preserve the traces of a very early Greek alphabet, older in part than the split between 'Western' and 'Eastern' Greek alphabets, since it preserves all three Phoenician sibilants, samekh, sade and šin, which neither 'Western' nor 'Eastern' Greek alphabet possesses any longer ( $s$ is written with either sigma or san; archaic Etruscan had two different sounds, written with altogether four characters). ${ }^{116}$ The borrowing of the Euboean alphabet to write Etruscan surely goes

${ }^{108}$ Ridgeway 1992, 93; cf. Bartoněk and Buchner 1995, 204-05, who republish the inscription. Pausanias (8. 21. 3) says that Olen of Lycia applied this epithet to Eileithyia in his Hymn to her (the semi-mythical poet Olen's fragments seem never to have been collected).

${ }^{109}$ Lane Fox 2008, 133, after Colonna 2005, who took it as 'hands off'.

${ }^{110}$ The negative ought to be spelled nei as in other early Latin inscriptions, e.g. no. 3 in Ernout 1966, 7-9, cf. 44, and the Garigliano bowl (see Baldi 2002, 200-02).

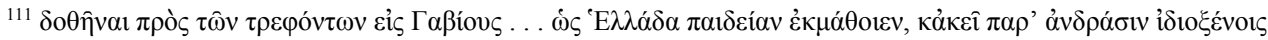

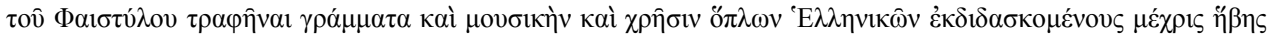
(Ant. Rom. 1. 84. 5); cf. Plut. Vit. Rom. 6. 2; Plut. Mor. 320E; Steph. Byz. s.v. Tóß1or (sic). The passage was adduced by Peruzzi 1992, 459. The truth of this report has of course been doubted (Ampolo 1997, 211-17).

${ }^{112}$ Colonna 1980; $c f$. Bartoněk and Buchner 1995, 205. Baldi 2002, 126, dates it to $c .620-600$.

${ }^{113}$ Demand 2013, 245-46. For a more exclusively Euboean interpretation see Lane Fox 2008, 136-58.

114 This theory was floated by Segert 1977, and with more conviction by Holloway and Holloway 1993; contra, Bartoněk and Buchner 1995, 183.

115 Johnston 1990, 426.

${ }^{116}$ Bonfante and Bonfante 2002, 52-55. See further Malkin 1998, 161-68. 
back into the Geometric period; the earliest Etruscan inscription dates from $c .700,{ }^{117}$ and the model abecedaria from Etruria, like the one from Marsiliana d'Albegna, dated 675650, have the five-stroked Eretrian mu and not its Chalcidian four-stroked variant. ${ }^{118}$ Euboean contact with Veii can be documented as early as the start of Middle Geometric II, i.e. c. $850-825$ according to the new chronology. ${ }^{119}$ The earliest alphabets so far known in Italy already had the supplemental letters, since the Etruscan model abecedaria include them in the order $Y X \Phi Y,{ }^{120}$ and the early Latin alphabet included chi $(X$ or +$)$ after $V$ with the sound-value $k s$ as in Euboean script, as in IOY+WEYTA iouxmenta on the Lapis Niger from the forum in Rome.

If the inscribed flask from Gabii is rightly dated to $c .825$ at the latest, one of two conclusions follow. Either (i) the alphabet with vowels is first attested in Italy (yet, as we have noted, this is a developed version of it); or (ii) the chronology of Iron Age Greece needs to be revised upwards too, in which case the texts from Lefkandi and Eretria may be just as early as that from Gabii. Although the 'Cretan' alphabet seems the oldest, it may not have been native to Crete, but rather to Eretria and its overseas settlements.

Given the presence of Middle Geometric II inscriptions in Eretrian script at Eretria, one is inclined to take more seriously the ancient traditions that the alphabet was invented by a Euboean seafarer (Palamedes!). ${ }^{121}$ The most suggestive of these is Plutarch's story that Palamedes added four letters to the sixteen of Cadmus, and Simonides added four more, ${ }^{122}$ which are specified elsewhere as $H, \Xi, \Psi$ and $\Omega .{ }^{123}$ The latter detail makes excellent historical sense if Simonides introduced Ionic script to the Athenians, who did not use these letters in their epichoric alphabet, since they wrote xi as XS and psi as $\Phi$ S. Pliny specifies Palamedes' extra letters as Z, Y, $\Phi$, and $X ;{ }^{124}$ it is odd that Z is included, but the others are the first three supplementals. When Herodotus claims that the Ionians who dwelled round about the Cadmeans took over the Phoenician letters from them, ${ }^{125}$ he may be telling the same story, since his 'Ionians' are surely Euboeans, who may have controlled parts of Boeotia before the Lelantine War. ${ }^{126}$

\footnotetext{
${ }^{117}$ Wallace 2008, 17.

${ }^{118}$ See the illustration in Bonfante and Bonfante 2002, 130, with Table 1 in $\S 5$ below.

119 Tandy 2000, 66-72, esp. 66; Lane Fox 2008, 132-33.

${ }^{120}$ Bonfante and Bonfante 2002, 130.

${ }^{121}$ So first Stesichorus fr. 213, from his Oresteia Book 2. Cf. Powell 1991, 233-36, who is followed by Ruijgh $1995,39$.

${ }^{122}$ Plut. Mor. $738 \mathrm{~F}=$ Quaest. Conv. 9. 3.2.

${ }^{123}$ Scholia to Dionysius Thrax i. 185.5 Hilgard.

${ }^{124}$ Palameden adiecisse quattuor hac figura ZYФX, totidem post eum Simoniden melicum $\Psi \Xi \Omega \Theta$ (Nat. Hist. 7. 192).

${ }^{125}$ Hist. 5. 58.

${ }^{126}$ Buck, R.J. 1979, 79, 100; cf. Jeffery 1979, 63-64, and Parker 1997, 167.
} 


\section{$\S 4$. The origins of the Phrygian and Lemnian scripts}

External evidence from the other end of the Greek world comes from Gordion in northwest Anatolia. As in many early Greek inscriptions, the ductus of the early Phrygian inscriptions is tall, the omicron is small, and vertical dots are used to separate words or phrases. No abecedaria are known. The supplemental letters are $\mathrm{Y}$ for $u$ (alongside $\mathrm{F}$ for $w$ ), a sampi $\uparrow$ or $\mathrm{T}$ for $t^{s}$ that resembles Ionic $\mathrm{T},{ }^{127}$ a sign $\checkmark$ or $\mathfrak{l}$ for $y$ (alongside I for $i$ ), ${ }^{128}$ and a $\psi$ of obscure sound-value. Zeta, eta, theta, xi, șāde , san, phi and omega are unattested. As we saw in $\S 1$ above, Phrygian uses the 'long' sigma as well as sigmas with three or four bars. Like early Greek inscriptions but unlike West Semitic, Phrygian inscriptions run boustrophedon as well as from left to right and from right to left.

The first Phrygian inscriptions have been redated to much earlier than formerly, and this redating has the potential dramatically to affect the history of the Greek alphabet, as Brixhe pointed out. ${ }^{129}$ First, the timbers that support the roof of the great Tumulus MM, which was formerly ascribed to King Midas in the 720s but more probably belongs to his predecessor Gordias, have been decisively redated by dendrochronology to 743-741 BC. ${ }^{130}$ In 2007 Richard Liebhart found inscribed on these wooden beams four names, some of which also appear in the inscriptions on wax that were found with the burial; ${ }^{131}$ these must date from $c .740$. Above all, the destruction-level of the citadel at Gordion, which had been dated to $c .690 \mathrm{BC}$ by a suggested association with the Cimmerians' sack of the city around that date, has been conclusively redated by radiocarbon analysis to $c .805$, more than a century earlier. Inscriptions on pottery found above this destruction-level are now dated to the first half of the eighth century, from $c .800$ down to $c .750$ BC. At least three, G-237, G-249, and G-104, two of them from left to right, come from the lowest level of phase 6a, perhaps with G-202 as well; ${ }^{132}$ this level should belong to the early eighth century, since rebuilding immediately followed the fire. According to the traditional chronology, these texts seem to antedate any Greek inscriptions that are known ${ }^{133}$ - unless of course that from Gabii is in Greek. Hence Brixhe dates the Phrygian alphabet before the Greek, and suggests that knowledge of the Phoenician script reached Phrygia overland across Anatolia, where it was used beside hieroglyphic Luwian in the kingdom of Que/Cilicia, ruled by the house of Mopsus, and even at Ivriz north of the Taurus range. ${ }^{134}$

Brixhe has ingeniously argued that the original alphabet created two different forms from West Semitic $y \bar{o} d$, viz. the upright iota I, which it used to express vocalic $i$, and the

\footnotetext{
${ }^{127}$ No. 22 in the table of the alphabet of Gordion in Brixhe and Lejeune 1984. The fact that sampi was located at the end of the alphabet after omega in the mid-seventh century Samian abecedary suggests that it was a later addition to that script (Johnston 1990, 471, no. Ia, with pl. 79 no. 7).

${ }^{128}$ So first Lejeune 1969.

${ }^{129}$ Brixhe 2004; $c f$. Lemaire 2008, 51-52. For the archaeological implications see Rose, Darbyshire and De Vries 2011.

${ }^{130}$ Manning et al. 2001; Manning et al. 2003.

${ }^{131} \mathrm{http}: / /$ sites.museum.upenn.edu/gordion/articles/history/28-funeralmm.

${ }^{132}$ Brixhe 2002, 22 with n. 15; Brixhe 2004, 276. Sass 2005, 147, prints G-239 instead of G-249.

${ }^{133}$ Brixhe 2004, 278, who does not refer to Gabii.

${ }^{134}$ Brixhe 2004; $c f$. Sass 2005, 148; Lemaire 2008, 51-52.
} 
sign $\checkmark$ or 1 for $y$, which he derives from the crooked iota; he compares the creation of wau and hypsilon from Phoenician wāw. Both forms are used in the Phrygian alphabet, but not of course in Greek, where, Brixhe argues, crooked iota was replaced with the upright bar to avoid confusion in those scripts where, rather than use 'san' $M$, sigma was employed in the forms $\zeta, \Sigma$, or with any number of bars in between. Brixhe believes that the sign for $y$, i.e. $\checkmark$ or 1 , would have been placed at the end of the alphabet. ${ }^{135}$

Unfortunately, however, we do not know the sequence of the Phrygian abecedarium. Confusion between crooked iota and its twin three-barred sigma was certainly a risk; the two signs occur together only on the Dipylon oenochoe, where confusion is avoided by reversing the direction of the three-barred sigmas. ${ }^{136}$ However, although the use of $\checkmark$ or $l$ as $y$ could conceivably be a sign of the great antiquity of the Phrygian alphabet, other letter-forms decisively prove that Phrygian script cannot itself be the origin of the Greek alphabet or result from a simultaneous adoption, but was already a modified form of it. First, Phrygian uses a mu with four strokes, as in the alphabets of Chalcis, Corinth, Aeolis, and Ionia, rather than with five, as in that of Crete, Eretria and the West Semitic model. Second, the Phrygian lambda is neither the Euboean or West Semitic $L$, but is inverted to $r$ as in the Corinthian, Ionic, and Aeolic alphabets (and in some forms of 'Cretan'). Finally, Phrygian never uses the dotted omicron. Hence Phrygian borrowed from a Greek alphabet that is more developed than Cretan and Eretrian. The closest parallels are in fact with the scripts of Aeolis and Lemnos, as we will see.

A script rather like Phrygian is found in the Lemnian script on the stele from Kaminia in Lemnos, which encodes an epitaph in a form of Etruscan. ${ }^{137}$ Like early Greek and Phrygian inscriptions, the Lemnian texts are written either boustrophedon or in Schlangenschrift, with the first line written from right to left in both cases. This script uses inverted lambda $\Gamma$ and four-stroked mu (as in Phrygian), a square omicron in inscription B (as sometimes in Phrygian), a dotted omicron $\odot$ in inscription A (this is not found in Phrygian), four-bar sigma $\Sigma$, and $\Psi$ for $k h$, together with $\mathrm{日}$ and $\Phi$ (neither is found in Phrygian); it employs $K$ and $O$ where Etruscan uses ( and $Y$. Although the Lemnian sign $\checkmark$ is normally transcribed $s$, $\checkmark$ must be zeta $\left(t^{s}\right.$ ?), since JIFAI is from the same root as Etruscan zivas 'having lived'. ${ }^{138}$ By this principle, the Lemnian words $\Sigma$ IRLYFEI: $\checkmark$ and

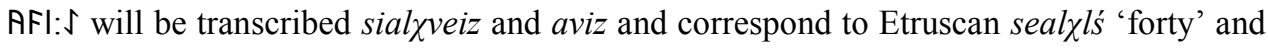
avils 'years', where $z$ would be an easy sound-change from $l s$; the dicolon where $l$ appears in Etruscan surely conveys phonological information. ${ }^{139}$ Since the Lemnian letter $\checkmark$ looks like the Phrygian sign $\checkmark$ or $\mathcal{l}$ for $y$, and the crooked iota is not present in either the Aeolic

\footnotetext{
${ }^{135}$ Brixhe 2004, 281-83. Brixhe (1982, 40, 167-71, 176-77) suggested that Eteocretan used crooked iota $\checkmark$ for $i$ and 7 for $y$, but there is only one instance of the supposed $y$; Jeffery 1990 [1961], 308-09, had taken $\checkmark$ as chi.

${ }^{136}$ Brixhe 2004, 283 n. 9. The reversal is common even where there are no crooked iotas, e.g. on the cup of Nestor.

${ }^{137}$ Bonfante and Bonfante 2002, 60-62 with fig. 4; Wallace 2008, 218-21 with fig. 12.1.

138 This suggestion, which I sent in an unpublished paper to Larissa Bonfante in 2005, has now been advanced independently by Eichner 2012, 14. This form of zeta is otherwise unknown, but could easily have resulted from the transformation of I under the influence of the sloping diagonals of $E$ and $F$.

${ }^{139}$ So Wallace 2008, 21.
} 
or the Lemnian or the Rhodian scripts, one wonders whether this Phrygian sign $\checkmark$ or 1 for $y$ is in fact a reapplication of zeta or an independent variation on the upright iota rather than a descendant of the crooked iota of 'Cretan' script.

The Greeks had no recollection of having borrowed the alphabet from the Phrygians;

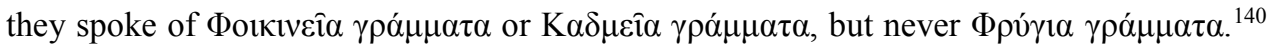
Jeffery suggested that the Phrygian letter-shapes are closest to those of inscriptions from Aeolis, which have inverted lambda and four-stroked mu. ${ }^{141}$ She plausibly suggested that the link between Phrygia and Euboea was Aeolian Cyme; for the settlers of Aeolis were from Thessaly, Boeotia, and Euboea, as we know from both their traditions and their dialect. The inhabitants of Aeolian Cyme, like those of Campanian Cyme (Cumae), must have named their settlement after the town of Cyme on the east coast of Euboea opposite Aeolis. ${ }^{142}$ Tradition recounts that the daughter of a certain Agamemnon, king of Aeolian Cyme, married a Phrygian king called Midas. ${ }^{143}$

Although Jeffery compared the Lemnian alphabet to Phrygian, ${ }^{144}$ it must instead be adapted from an alphabet like those of Rhodes, Phocis, East Locris, the central and southern Peloponnese, or Thessaly, since these scripts use $\Psi$ for $k h$ as well as the inverted lambda and four-stroked mu. East Locris or Thessaly seem the most likely in geographical terms, but these roving Etruscans could have learned their script anywhere, perhaps even on mercenary service with Rhodians in Egypt. What is clear is that they did not learn to write in Etruria. ${ }^{145}$

Could we be sure that $\Psi$ stands for $k h$ in Phrygian script also, it would become more likely that the Phrygians derived their script from that same source (or even from Lemnian itself) rather than from Aeolis, because in Aeolic script $X$ stands for $k h$ and $\Psi$ for $p s$; however, the value of $\Psi$ in Phrygian remains obscure for now. But at least it is certain that the adoption of writing in Phrygia is not attested as early as in Latium, if the date of the inscription from Gabii holds firm, and that the Phrygian letter-forms show that Phrygian script derives from that of Greece.

\section{$\S 5$. Confusions of sibilants and the origins of the Roman alphabet}

The use of three-barred and four-barred sigmas alongside 'san' $M,{ }^{146}$ and the use of $\mathrm{X}$ as a sibilant of some kind in many early alphabets, have both occasioned much scholarly

\footnotetext{
${ }^{140}$ Jeffery $1982,833$.

${ }^{141}$ Jeffery $1979,92$.

${ }^{142}$ Jeffery 1979, 92, and 1982, 832; cf. Powell 1991, 16.

143 Aristotle, Constitution of the Cymaeans fr. 611.37 Rose, in the epitome of Heraclides Lembus (Dilts 1971, 27).

${ }^{144}$ Jeffery 1990 [1961], 299.

${ }^{145}$ Malzahn 1999.

146 'San' is a misnomer, since, as McCarter showed (1975, 100-01, n. 88), the Canaanite letter-name for šin (the origin of sigma) was $\check{s} a n$, which was cited in Akkadian as $\check{s} a$; hence 'san' is properly another name for sigma (cf. Woodard 1997, 184-86). We do not know the Greek name for 'san' M. As Woodard rightly suggests (1997, 186), the Greeks often regarded the sign $M$ as simply a rotated variant of $\Sigma$, itself rotated from Phoenician šin W.
} 
discussion. ${ }^{147}$ The two problems are in fact linked. Table 1 lists the complete abecedaria that survive from the archaic period. ${ }^{148}$ The signs $\zeta_{2} \Sigma$, ,, , $, M, \zeta_{2} \Sigma, X$ and $\Psi$ stand for 'crooked iota', xi, san at Caere versus san elsewhere, sigma with three or four bars, chi and psi respectively, according to their various positions and the sound-values of the supplemental letters.

\begin{tabular}{|c|c|}
\hline $\begin{array}{l}\text { origin (pl. \& no. in Johnston 1990) } \\
\text { and sound-values of supplementals }\end{array}$ & $\begin{array}{l}\text { sequence of alphabet } \\
\text { (shapes shown left to right) }\end{array}$ \\
\hline Schøyen tablets (Scott et al. 2005) - & $\alpha \beta \gamma \delta \varepsilon f \zeta_{1} \theta_{2 k} \lambda \mu \nu \boxplus o \pi \Upsilon^{\gamma} \circ \rho \Sigma_{T}$ \\
\hline $\begin{array}{l}\text { Eretria, shrine of Apollo (Kenzelmann Pfyffer } \\
\text { et al. 2005, no. 3) } \mathrm{X}=k s, \psi=\chi\end{array}$ & {$[\alpha \beta \gamma \delta \varepsilon f \zeta \vdash \theta t \kappa \lambda \mu \nu] \mathbb{\boxplus o \pi}[\quad$ - - } \\
\hline $\begin{array}{l}\text { Etruria, S., Caere (pl. 48, 19) } S / 2 / \Sigma / X=s, \\
\text { Etruria, S., Viterbo (pl. 48, 22) } \Psi=\chi \\
\text { Etruria, S., Formello/Veii (pl. 48, 20) } \\
\text { Etruria, central, Marsiliana (pl. 48, 18) } \\
\text { Etruria, N., Siena (pl. 48, 23) }\end{array}$ & 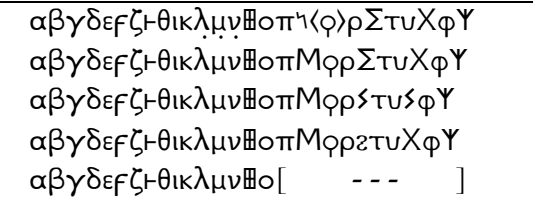 \\
\hline Laconian? krater $(\mathrm{pl} .39,66) \mathrm{X}=k s, \boldsymbol{Y}=\chi$ & $\alpha \beta \gamma \delta \varepsilon f \zeta \vdash \theta 1 \mathrm{~K}[--]_{\phi} \Sigma \mathrm{\tau} X Y$ \\
\hline Metapontion (pl. 50, 19) $\mathrm{X}=k s, \Psi=\chi$ & $\alpha \beta \gamma \delta \varepsilon \in \zeta \vdash \theta<\kappa \lambda \mu \nu \circ \pi \rho \rho M \tau \cup \varphi Y X X$ (sic) \\
\hline Messapia, Vaste (pl. 53, 15) $\mathrm{X}=\check{s}, \Psi=$ ? & 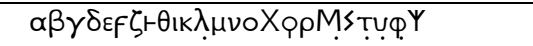 \\
\hline Boeotian cup (pl. 10, 20) $X \Sigma / \Psi \Sigma=k s, \Psi=\chi$ & $\alpha \beta \gamma \delta \varepsilon f \zeta \vdash \theta \mathrm{I} k \lambda \mu \nu \circ \pi \rho \sum \tau u X_{\phi}{ }^{Y}$ \\
\hline Attica, Vari (Langdon 2005) $\mathrm{X} S=k s, \mathrm{X}=\chi$ & 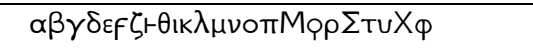 \\
\hline $\begin{array}{l}\text { Corinth, Penteskouphia (pl. 20, 16) } \Xi=k s, \\
\text { Corinthian aryballos (pl. 74, 2-3) } \mathrm{X}=\chi\end{array}$ & 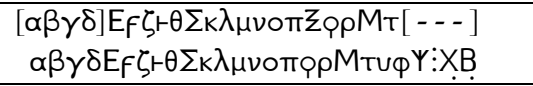 \\
\hline Samos, Heraeum (pl. 79, 7) $\equiv=k s, \mathrm{X}=\chi$ & 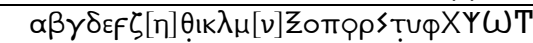 \\
\hline
\end{tabular}

Table 1. Extant archaic alphabets showing iota, sibilants and chi

In these discussions the fate of the Phoenician sign $r s \underline{a} \bar{d} d \bar{e}$, with the sound $t^{s},{ }^{149}$ has not been clearly brought out. The Greeks clearly did not know what to do with this sibilant, which was for most of them redundant. But they generally preserved it in the alphabet; indeed, I believe that the existence of a Phoenician letter that they heard as $t s$ caused many of them to treat $k s$ as a sound-group worthy of its own sign. ${ }^{150}$ Thus a sign resembling the three-barred sigma, namely 3 , appears in the script of Mantinea in Arcadia, but stands for an affricate such as $t^{s}$; although its place in the Arcadian abecedarium is unknown, it is surely the direct descendant of the shape $r$ and sound $t^{s}$ of $s \bar{a} \underline{d} \bar{e}^{151}$ In the Etruscan alphabet from Caere the sign $५$ stands after pi in the alphabetic series, i.e. where șāde and

\footnotetext{
${ }^{147}$ e.g. Powell 1991, 46-63; Ruijgh 1995, 32-36; Woodard 1997, 147-204.

${ }^{148}$ For completeness' sake I include the Schøyen tablets, even though I do not believe that they are authentic.

${ }^{149}$ For this sound-value for șādē see Powell 1990, 46; Ruijgh 1995, 32-34; Woodard 1997.

${ }^{150}$ Pace Woodard 1997, the Cypriot syllabic signs )( for $x a$ and ( $t$ for $x e$ may have been devised because Ionic Greek script had a sign $\Xi$ with the value $k s$, rather than vice versa.

${ }^{151}$ Larfeld 1914, 218, 220-21. Jeffery 1990 [1961] 212-13 wrongly regards the Mantinean sign as an innovation. The Arcadians did not otherwise employ 'san' M, and mainly used a four-barred rather than a three-barred sigma.
} 
'san' M belongs. The Corinthian alphabet from Penteskouphia has moved the sign 1 , descended from samek $(s)$, to the place of șâde (in Corinthian inscriptions 1 has the value $k s$ ), and both Corinthian alphabets have replaced sigma with $\mathrm{M}$.

The similarity between the shape $\zeta$ of $s \bar{a} \underline{d} \bar{e}$ and that of three-barred sigma $>$ caused much confusion. The alphabet from Formello near Veii has a sign $>$ after hypsilon and before phi, i.e. in place of chi. ${ }^{152}$ This sign is again a form of $s \bar{a} \underline{e} \bar{e}$, but is placed at the end as equivalent to chi; for the alphabets of southern Etruria all put chi $(\mathrm{X}$ or + ) after $\mathrm{Y}$, but give it the sound-value of a sibilant (often transcribed $\dot{s}$ ). Similarly, on the island of Sicinus, which used an archaic 'Cretan' script with crooked iota $>$ and 'san' M, a sign S which somewhat resembles three-barred sigma was used to write $k h$ in the word

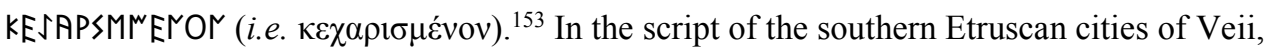
Caere and Tarquinia, $\mathrm{X}$ was used interchangeably with the signs $\zeta$ and $\Sigma$ for $s$, as opposed to the other sibilant conventionally transcribed $s$, which was written with 'san' $\mathrm{M}^{154}$ Similarly, in Messapian the sign $\mathrm{X}$ or + was used for a sibilant $\check{s}$. However, in the Messapian abecedarium $\mathrm{X}$ stands in the place of $s \bar{a} \underline{d} \bar{e}$, not in that of xi after nu (Table 1). Messapians also used sigmas with three to five bars for $s$; we do not know the value of 'san' M, which was not used in inscriptions and was probably a 'dead' letter in their abecedarium. ${ }^{155}$

The earliest attestation of $\mathrm{X}$ as $k s$ is on the foot of a krater of $c .720$ that was made in Euboea and inscribed before firing. This vessel, found at Pithecussae in grave 168 (the

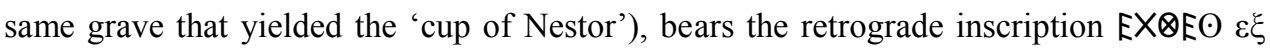
$\theta \varepsilon \overline{0} .{ }^{156}$ The Lapis Niger uses + for $k s$ in IOY + ${ }^{N} E{ }^{N T A}$ iouxmenta, i.e. iumenta 'pack animals'; the presence of $\mathrm{X}$ as $k s$ in the Roman alphabet proves that this equivalence goes back to the beginnings of writing in Italy. The use of $\mathrm{X}$ for a sibilant in Etruscan and Latin must be connected with the sound-value of chi X as $k^{h} s$ in the Euboean alphabet. ${ }^{157}$ This is often thought to have arisen from the writing of $k^{h} s$ with $X>$ as in Attic, Boeotian and Rhodian; ${ }^{158}$ the earliest attestation of $X S$ as $k^{h} s$ may be at Methone (inscription no. 22), if retrograde $3 \times \mathrm{XYI}$ is a metathesis of $\chi \sigma \varepsilon v 1-$, i.e. $\xi \varepsilon v 1-.{ }^{159}$ But the hypothesis that Euboean $\mathrm{X}$ as $k^{h} s$ is simplified from $\mathrm{X}>$ seems uneconomical, because the sound-value $k s$ was applied to another single sign, namely xi $\Xi$, in other Greek alphabets. I suggest instead that the use

\footnotetext{
${ }^{152}$ See Bonfante and Bonfante 2002, 132 fig. 11d. Jeffery 1990 [1961], 237, regards this as a mistaken repetition of sigma.

${ }^{153}$ Jeffery 1990 [1961], 39, 322, 324 no. 27, with pl. 62 (27).

${ }^{154}$ Bonfante and Bonfante 2002, 78; Rix 2004, 945; Wallace 2008, 21-22.

${ }^{155}$ See A. Santoni at http://lila.sns.it/mnamon/ s.v. Messapico.

${ }^{156}$ Bartoněk, A., and Buchner 1995, 177-78 no. 44; the next attestation is from Laconia, c.650-600 (Johnston 1990, 446 no. 1a).

${ }^{157}$ The Greeks naturally felt an aspirate in a consonantal cluster ending with sigma, as in the Naxian spelling $h \sigma$

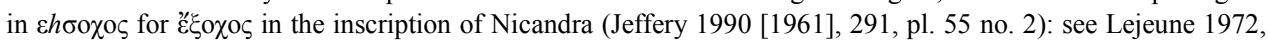
72.

${ }^{158}$ Jeffery 1990 [1961] 36 with earlier references.

${ }^{159}$ This was suggested by Johnston and Méndez Dosuna (both forthcoming in Tzifopoulos and Clay).
} 
of the sign $\mathrm{X}$ or + as $k s$ arose from an easy confusion between the shapes of the signs $r$ $s \bar{a} \underline{d} \bar{e}$, i.e. $t^{s}$, and + chi, which was often written as a vertical upright with a diagonal crossbar. ${ }^{160}$ The listing in the Messapian abecedarium of $\mathrm{X}$ in the place of $s \bar{a} \underline{d} \bar{e}$ surely gives strong support to this theory.

The use of X with the value $k s$ in Latin, exactly as in Euboean, is a strong argument against the view that the Romans borrowed the alphabet exclusively from the southern Etruscans, who used $\mathrm{X}$ as $\dot{s}$. The Romans must have adopted the value $k s$ for $\mathrm{X}$ from Eretrians in Italy, just as they maintained the Eretrian values of $B, D, O$, and $X$, letters which were not used in Etruscan, and just as they took over from the Eretrians the dotted omicron for $\bar{o}$ in the inscription EALYET@DTITA salvetód Tita. Yet the Romans shared with the Etruscans their use of ( for both the voiceless velar $k$ and the voiced $g$ and the digraph $\mathrm{FE}$ for the sound $f$. Thus the Vendia inscription from Rome of c.620-600 runs ECOYPMATITAYEMDIASN ${ }^{\mathrm{N}} \mathrm{N}^{\mathrm{N} A P}\left[\right.$, i.e. ego urna Tita $<s>$ Vendias Mamar $\left[{ }^{161}\right.$ and the Praenestine fibula has FEE:FERKED fefaked, i.e. 'fecit'. It is remarkable how much closer these letter-forms are to Eretrian script, with five-stroked mu, than to what we normally think of as Roman script. If the Romans did obtain the alphabet from the Etruscans, as is the standard view, they must have derived the values of $B, D$ and $O$ and $X$ from unused 'dead' letters in their abecedarium. ${ }^{162}$ But an Etruscan explaining the values would surely have mispronounced these letters, and the early use of dotted omicron for $\bar{o}$ in the inscription salvetōd Tita from Gabii is also a problem for this theory. The Sabine alphabet may also have been borrowed directly from Greek, since it uses O. ${ }^{163}$

In the alphabets of Euboea, Boeotia, Attica, ${ }^{164}$ Rome, and Etruria the original order of the supplemental letters was $\mathrm{X} \Phi \Psi$, with the values $\mathrm{X}=k^{h} s, \Psi=\chi$. Although it is not clear when these supplementary letters were added to the alphabet, with what values and in what order, it must have happened before $c .750$ by the traditional chronology, since $\psi$ already occurs with the value $k h$ at Lefkandi on a Late Geometric I ostracon in the retrograde sequence $\alpha \iota \sigma \chi \rho .[\bar{o} v]$, i.e. Ai $\sigma \chi \rho i \omega v,{ }^{165}$ and at the sanctuary of Apollo at Eretria in the retrograde Late Geometric dipinto which I would restore $[K \alpha] \lambda \chi \alpha \delta \varepsilon \overline{0} \bar{\varepsilon} \mu 1{ }^{166} \psi$ represents $k h$ on the Dipylon oenochoe, while $\Phi$ appears on the cups of Nestor and Philion. $\mathrm{X}$ as $k h$ is found on the early inscription from Corinth which Jeffery dates to c. 700 but Stillwell had dated to $750-725 .{ }^{167}$ 王 is attested at Corinth with the sound-value ks by c.675-650. ${ }^{168}$

\footnotetext{
${ }^{160}$ So the abecedaria of Marsiliana, Caere, and Metapontion (see Table 1).

${ }^{161}$ Baldi 2002, 126. The $\mathrm{S}$ is written retrograde.

${ }^{162}$ So Wallace $2011,10-12$.

${ }^{163}$ Crawford 2011, i. 9-10, with further references.

${ }^{164}$ Langdon 2005.

165 Jeffery 1979, pl. 69; Bartoněk and Buchner 1995, 196.

${ }^{166}$ Kenzelmann Pfyffer 2005, 59 no. 1, who needlessly reads $[X \alpha] \lambda \chi\langle 1\rangle \alpha \delta \varepsilon \overline{0}$, wishing to connect the name to Chalcis. However, a derivative of Ká $\lambda \chi \alpha \varsigma$ is perfectly acceptable.

${ }^{167}$ Jeffery 1990 [1961], pl. 18 nos. 1a-b; cf. Powell 1991, 132-33.

${ }^{168}$ Jeffery 1990 [1961], 115 with pl. 18 no. 4.
} 


\section{§6. Conclusion}

In short, if the new chronology of the phases of the Geometric period in the Aegean is proved to be correct, the inscription from Gabii shows that the earliest known form of the Greek alphabet, which already included the additional letter Y, was created between $c .850$ and $c .825 \mathrm{BC}$ at the very latest, with inscriptions from Gordion known by shortly after 800 $\mathrm{BC}$ and from Euboea around $c .775$ by the traditional chronology. The peculiar fact that Gabii and Gordion have inscriptions that are dated earlier than those from Euboea, which lies in between, suggests that the new higher chronology of the Geometric period is likely to be correct (see $\S 3$ above), and that the Middle Geometric II texts from Eretria and Lefkandi are in fact contemporary with those inscriptions.

In any case, the first phase of adaptation was the addition of hypsilon and the creation of the upright iota. The word-divider becomes three vertical dots rather than a vertical bar, to avoid confusion with the upright iota. In all other respects the letter-forms were the same as the Phoenician alphabet of the time and no earlier, but two Aramaic variant forms were added, i.e. the dotted omicron and the dots for punctuation. Inscriptions were on folding writing-tablets ( $\delta \varepsilon \dot{\lambda} \tau$ ot, borrowed from the Phoenician term for 'doors'), papyrus ( $\beta$ $\beta\langle\lambda$ os, another Phoenician term) or other perishable materials.

If this earliest script was a Cretan invention, it survived in its original form only among the Cretans and their neighbours; for Crete was a very conservative island and used writing for far more limited purposes, mainly written laws, than did other regions of Greece. ${ }^{169}$ In any case, the Eretrians quickly adapted it, either in Euboea or even at Pithecussae, and took it on early voyages between Greece and Italy, where they quickly passed it to the Latins and Etruscans. The Eretrians innovated by adding sides to the xi and extra strokes to the sigma. The addition after hypsilon of the supplemental letters phi, chi and psi happened before Late Geometric I, when these letters are first attested in inscriptions, and may well have occurred when the Eretrians first began to write; it must certainly be ascribed to them and not the Cretans, since the latter never used these letters and did not transmit them to Thera and Melos. Achaea and Corinth were other early adopters, as was Rhodes; all three are on major sea-routes. The Etruscans who settled on Lemnos may have adapted the script of Rhodes.

In turn, the Chalcidians borrowed Eretrian script (with a four-stroked mu). The Phrygians borrowed it from them, possibly via Aeolis, by c. $800 \mathrm{BC}$ or soon after.

\section{§7. Epilogue: the alphabet and early Greek poetry}

The existence at Methone of pots of local manufacture with alphabetic inscriptions does not show that Methone was one of the places where the alphabet was first used, ${ }^{170}$ since Greek script seems already to have been about a century old before Methone was founded in 734/3 BC. However, because of the cup of Acesander from Methone we can affirm with increased confidence the lesson of the Late Geometric Ib Dipylon oenochoe, the Late Geometric II cup of Nestor, and the similar retrograde three-line verse-inscription on the cup from Eretria, namely that alphabetic writing was being used to record poetry at

\footnotetext{
${ }^{169}$ Similarly Ruijgh 1995, 43 n. 152.

${ }^{170}$ Besios, Tsifopoulos and Kotsonas 2011, 235, 553-4.
} 
celebrations and symposia by Late Geometric $\mathrm{Ib}$, for which the traditional date is $750-735$ $\mathrm{BC}$ (as we have seen, this date may well need to be raised). This inscription eloquently attests (in case evidence were needed) that forms of oral poetry other than the hexameter epos, in this case iambic verse, go back to the later eighth century. Euboean script was better adapted to this purpose than any previous writing, including the Cypriot syllabary, which did not mark aspirated stops.

It is odd how unpopular it has become to draw from the discovery of inscriptions like the cup of Nestor what seems the obvious corollary, namely that, by this time, alphabetic writing could be used to record poetry on more serious occasions and at far greater length. Perhaps the Museum at Lacco Ameno, ancient Pithecussae, is simply so remote from the usual itineraries of most scholars of early Greek epic that their sensibilities are lulled into doubting the reality of that very tangible and datable object, whose existence anyone can verify by taking the ferry from Naples to Ischia. The cup of Nestor reveals a practised style of writing, with dots to mark off the separate phrases. Although no punctuation is seen on the cup of Acesander or the cup with retrograde hexameters from Eretria, the sophistication of the writing is very similar, as is the uniformly retrograde direction of the script.

Jeffery is right that the earliest Greek inscriptions were written boustrophedon, but with the first line of each paragraph always running from right to left. ${ }^{171}$ On the cup of Nestor and that from Eretria each line of verse is regarded as a separate beginning, and would therefore start on the right; and we can assume that any early recording of Greek verse would have followed the same principle rather than be written boustrophedon, whether verse by verse, as in West's reconstruction of Hesiod's autograph text, ${ }^{172}$ or continuously, as in that Homer's original text by Powell. ${ }^{173}$ The cup of Acesander is another shining proof that verse was being written down by $735 \mathrm{BC}$ at the latest. Burkert ${ }^{174}$ advanced the celebrated argument, in which its own author had himself ceased to believe, ${ }^{175}$ that Iliad 9. 382-4 refers to the prosperity of Egyptian Thebes under the Twenty-fifth Dynasty (715-663) and to the display of wealth taken from it when it was sacked in 663 . Even if this were correct, ${ }^{176}$ it could never prove the entire poem to be so

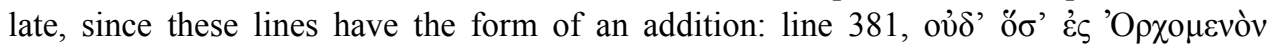

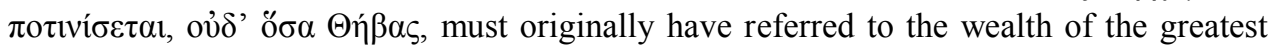
Boeotian cities of the Mycenaean world, while Airv $\pi \tau i \alpha_{\varsigma}$ etc. in line 382 is in addingstyle and changes the referent of 'Thebes'. Since the statistical evidence from the language of the hexametric epos shows that the Iliad is the oldest Greek poem we have, consistently antedating the works of Hesiod by a considerable margin, ${ }^{177}$ why should the Iliad itself not have been recorded in writing well before the end of the eighth century? ${ }^{178}$

\footnotetext{
${ }^{171}$ Jeffery 1990 [1961] 43-46, 311 (on 'Cretan paragraphing').

${ }^{172}$ West 1978, 60.

${ }^{173}$ Powell 1991, 65 fig. 7

${ }^{174}$ Burkert 1976, 5-21. The argument is still cited by West 2012, 236.

${ }^{175}$ Personal communication cited in Lane Fox 2008, 446 n. 35.

${ }^{176}$ But see Lane Fox 2008, 446 n. 35.

177 Janko 2012, 28 with fig. 1.3, rebutting critiques of Janko 1982 (further statistics appear in Janko 1992, $14 \mathrm{n}$. 19). I am surprised by the counter-arguments of Olson (2012, 12-15), who considers the well-known difficulties
} 
The new evidence from Methone makes it all the more likely that Euboeans played a significant role in the recording and diffusion of Homeric poetry. The theory of a Euboean contribution to the Homeric epics goes back to Wathelet, ${ }^{179}$ who observed that the restoration (most of the time) of the aspirate in Homer and the presence of isolated forms

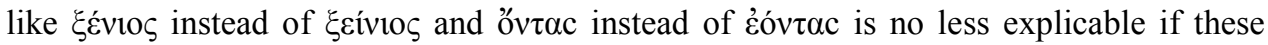
features are West Ionic than if they are Attic. There are only three such forms in the Iliad,

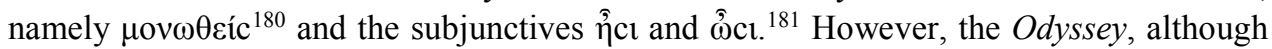

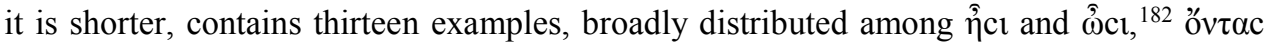

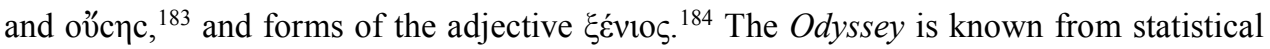
analyses of its language, and indeed from how it avoids reduplicating the events of the Iliad, to postdate the latter; but according to the statistics it can still be by the same poet, as it indeed is, in my judgement, since the Iliad and the Odyssey differ from each other less than do Hesiod's Theogony and Works and Days, which are definitely by a single poet. It may accord with this that the Euboean forms are so much more common in the Odyssey. Even so, the most recent stratum of Homeric diction remains East Ionic; there is only a thin scatter of Euboean forms. ${ }^{185}$ Such forms are hardly attested in Hesiod. ${ }^{186}$

As Ruijgh supposed, ${ }^{187}$ Homer probably acquired such Euboean forms from visits to the wealthy towns of Euboea; he would have gone via Delos, to which he refers in the Odyssey. ${ }^{188}$ Grandees of Eretria or Chalcis could well have played a crucial role in the writing down of one or both epics, supplying resources like copious rolls of papyrus from

in dating the Hymn to Aphrodite, with its text of only 293 lines providing a sample-size that is rather inadequate for statistical analysis, sufficient grounds to reject the comparative dating of the Homeric epics versus the two major poems of Hesiod, where the sample-sizes ('populations' in statistical terms) are far greater. If there is no genuine 'cluster' of linguistic results in its diction, the Hymn is simply the earliest case of 'false archaizing', viz. composition by a poet who learned from texts (possibly of the Homeric and Hesiodic epics as we have them) that were fixed at an earlier stage of the tradition, i.e. in writing. The much better discussion by Faulkner (2008, 23-47) rightly notes the frequency with which the poet modifies formulae in a post-Homeric manner and the likelihood that he knew our texts of Homer and Hesiod; he not implausibly assigns the poet to the later seventh century.

${ }^{178}$ In support of the eighth century dating of Homer see Powell (1991, 187-220) and Lane Fox (2008, 381-4), who dates the poems to $c .760-740$; for counter-arguments see now West 2012. Ruijgh's date for Homer of prior to $800(1995,21-4)$ still seems too high, however.

${ }^{179}$ Wathelet 1981.

${ }^{180}$ Il. 11.470.

${ }^{181}$ Il. 19. 202 and 14. 274.

${ }^{182} \mathrm{Od} .8 .147,162,580$ and $O d .24 .491$ respectively.

${ }^{183}$ Od. 7.94 and 19.489 respectively.

${ }^{184}$ Od. 14. 158, 14. 389, 15. 284, 15. 546, 17. 155, 24. 286 and 24. 314.

${ }^{185}$ West (1988) went further, in arguing that Homer also owed to Euboean dialect such forms as $\pi \hat{\mathrm{c}} \mathrm{c}$ rather than the $\kappa \hat{\omega} \mathrm{c}$ of East Ionic literature, which are of course found throughout the epos rather than as occasional variants. However, we know from Herodotus 1. 142 that there were dialectal distinctions in East Ionic for which we have no inscriptional evidence, and we cannot exclude that $\pi \hat{\omega} \mathrm{c}$ etc. were normal in considerable parts of East Ionia; indeed, forms in kappa like $\kappa \hat{c} \mathrm{c}$ are hardly ever found in East Ionic inscriptions (Buck, C.D. 1955, 63).

${ }^{186}$ ov̉cav is in Hes. fr. 204.91.

${ }^{187} 1995,46-50 ; 2011,295$.

${ }^{188}$ Od. 6. 162-64. 
their trading-partners in Byblos and indeed an amanuensis well skilled in taking dictation in the new art of writing. ${ }^{189}$ I doubt whether the pioneers at outposts like Methone had the leisure or resources to record such epics; but Pithecussae was conceivably such a large and important place in the eighth century that epics could have been recorded there. Indeed, Iliad 2. 783 probably refers to Pithecussae when it locates the battle between Zeus and Typhoeus at Arimoi: Strabo reports that some scholars located the combat there, since

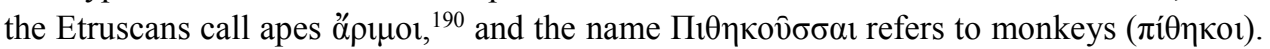
However, in the Phaeacian episode King Alcinous refers to Euboea as the most distant place to which his people have gone, which would be a good joke if the poem was performed there. ${ }^{191}$ The centrality of the Euripus to Greek navigation at this time is supported by the fact that catalogue of ships in the Iliad begins at Aulis, not to mention the borrowing of the term Graeci into Latin to denote the Greeks, when the Гранкоi were originally the inhabitants of the small town of Graea near Aulis. ${ }^{192}$ Hesiod too perfected his epic diction by attending performances at Chalcis, as he tells us himself. ${ }^{193}$ The Homeric poems belong in the heyday of Euboean wealth and exploration, ${ }^{194}$ before the decline that both Chalcis and Eretria suffered during and after the Lelantine War, which should be dated to no earlier than $700 .{ }^{195}$

The survival at Iliad 7. 238 of the inherited accusative singular $\beta \hat{\omega} v$ 'oxhide (shield)', like Sanskrit gām, instead of $\beta$ ov̂v has seemed to prove that a script with omega $\Omega$ was used to record the Iliad, since the word has apparently been normalized to ßov̂v everywhere else in Homer. ${ }^{196}$ Since the letter $\Omega$ may go back no further than $c .650$, when that letter finally appears on Samos, ${ }^{197}$ one could deduce that, contrary to my belief, an eighth-century text of Homer could never have existed. However, it now appears, as we saw in $\$ 2$ above, that some of the earliest Cretan, Euboean and Latin inscriptions used a dotted omicron to distinguish long $\bar{o}$ from $\breve{o}$; so an eighth-century Euboean text of the Iliad could already have transcribed $\beta \hat{\omega} v$ as $\mathrm{BOF}^{N}$, with a dotted omicron marking the long

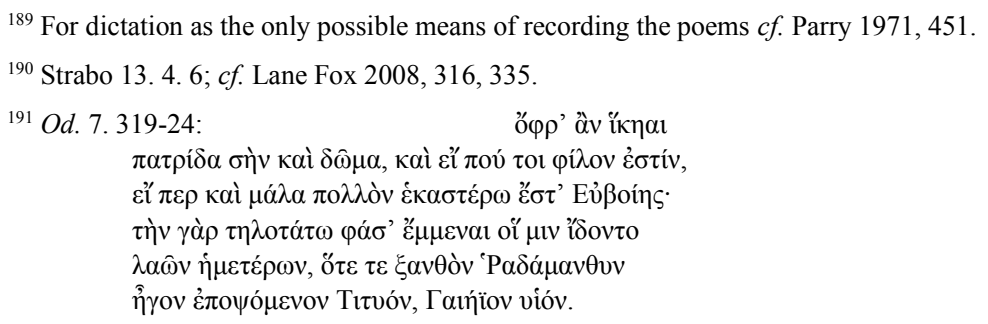

The myth that the Phaeacians took Rhadamanthys to see Tityus, who was from central Greece, is otherwise unknown; Hainsworth in his n. ad loc. suggests that Rhadamanthys would have disembarked at Aulis opposite Euboea.

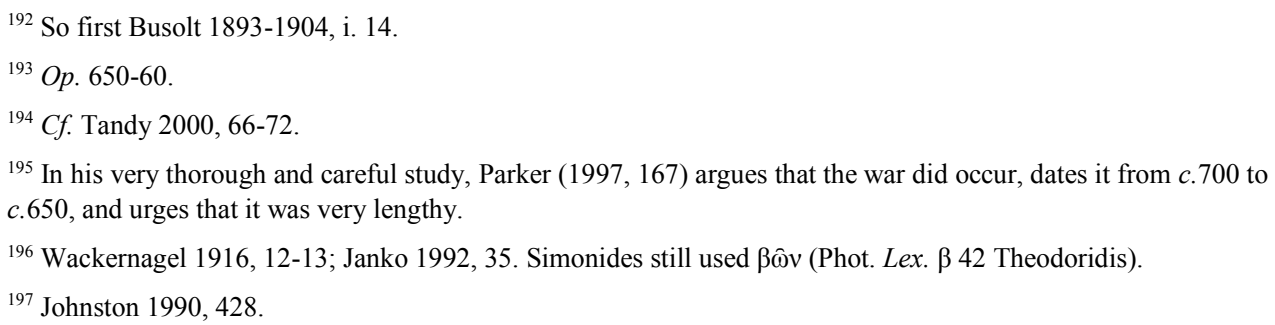


vowel. However this may be, Homer's epics could certainly not have been recorded in their present form without the use of alphabetic writing such as has now been found at Methone.

University of Michigan, Ann Arbor

\section{Bibliography}

Amadasi Guzzo, M. G. 2000. 'La transmission de l'alphabet phénicien aux Grecs', in R. Viers, C. de Vos, and D. Moatti (edd.), Des Signes pictographiques à l'alphabet: la communication écrite en Méditerranée, Paris and Nice: Karthala, 231-46.

Ampolo, C. 1997. 'L'interpretazione storica della più antica iscrizione del Lazio', in G. Bartoloni (ed.), Le necropoli arcaiche di Veio. Rome: Università degli studi di Roma 'La Sapienza', 211-17.

Andersen, Ø., and Haug, D. T. T. 2012. Relative Chronology in Early Greek Epic Poetry. Cambridge: Cambridge University Press.

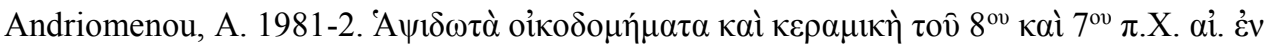

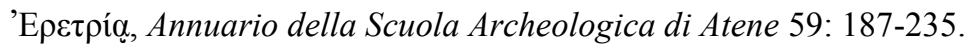

Baldi, P. 2002. The Foundations of Latin. Berlin and New York: De Gruyter.

Bartoloni, G., and Delpino, F. 2004. Oriente e Occidente: metodi e discipline a confronto. Mediterranea 1. Pisa: Istituti Editoriali e Poligrafici Internazionali.

Bartoloni, G., and Nizzo, V. 2005. 'Lazio protoistorico e mondo greco: considerazioni sulla cronologia relativa e assoluta della terza fase laziale', in Bartoloni and Delpino 2004, 409-36.

Bartoněk, A., and Buchner, G. 1995. 'Die altesten griechischen Inschriften von Pithekoussai (2. Hälfte des VIII, bis 1. Hälfte des VI, Jh.)', Die Sprache 37: 129-231.

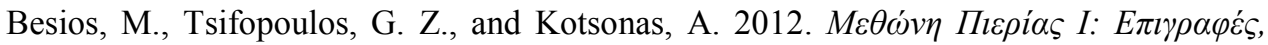

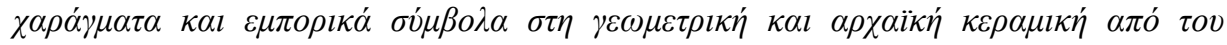

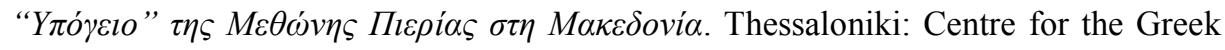
Language.

Bietti Sestieri, A. M. 2005. 'Intervento', in Bartoloni and Delpino 2004, 485-87.

Bonfante, G., and Bonfante, L. 2002. The Etruscan Language: an introduction. ${ }^{2}$ Manchester: Manchester University Press.

Bordreuil, P. 1993. 'Statue masculine à inscription bilingue assyro-araméenne au nom d'un personnage de Guzana (cat. 225)', in S. Cluzan, E. Delpont, and J. Mouliérac (edd.), Syrie. Mémoire et civilisation, Paris: Flammarion, 260-63.

Brixhe, C. 2004. 'Nouvelle chronologie anatolienne et date d'élaboration des alphabets grec et phrygien', Comptes rendus de l'Académie des Inscriptions et Belles Lettres: 271-89. 
Brixhe, C., and Lejeune, M. 1984. Corpus des inscriptions paléo-phrygiennes. Paris: Editions Recherche sur les civilisations.

Buchner, G. 1978. 'Testimonianze epigrafiche semitiche dell'VIII secolo a.C. a Pithekoussai', La Parola del Passato 179: 130-42.

Buck, C. D. 1955. The Greek dialects. Chicago: University of Chicago Press.

Buck, R. J. 1979. A history of Boeotia. Edmonton: University of Alberta Press.

Busolt, G. 1893-1904. Griechische Geschichte bis zur Schlacht bei Chaironeia. Gotha: Perthes.

Coldstream, J. N. 2003. Geometric Greece: 900-700 BC. Ed. 2. London and New York: Routledge.

Colonna, G. 1980. 'Graeco more bibere: l'inscrizione della tomba 115 dell'Osteria dell'Osa', Archeologia Laziale 3: 51-5 with Tavola X.

— 2003. 'Veii', Studi Etruschi 69: 379-82.

- 2005. 'Intervento', in Bartoloni and Delpino 2004, 478-83.

Crawford, M. H. et al., ed. 2011. Imagines Italicae: a Corpus of Italic Inscriptions. 3 vols., London: Institute of Classical Studies.

Csapo, E., Johnston, A. W., Geagan, D. 2000. 'The Iron Age Inscriptions', in Shaw, J. W., and Shaw, M. C. (eds), 2000, Kommos. IV, The Greek Sanctuary, Princeton University Press: 101-34.

Demand, N. 2012. The Mediterranean Context of Early Greek History. Cornwall-onHudson: Sloan.

Dilts, M. R. 1971. Heraclidis Lembi excerpta politiarum. Durham, N.C.: Duke University.

Docter, R. F., Niemeyer, H. G., Nijboer, A. J., and van der Plicht, J. 2005. 'Radiocarbon dates of animal bones in the earliest levels of Carthage', in Bartoloni and Delpino 2004, 557-75.

Duhoux, Y. 1982. L'Étéocrétois. Amsterdam: Gieben.

Eichner, H. 2012. 'Neues zur Sprache der Stele von Lemnos', Вопросы языкового родства (Journal of Language Relationship) 7: 9-33 (http://kak.znate.ru/docs/index17502).

Ernout, A. 1966. Recueil de textes latins archä̈ques. Paris: Klincksieck.

Fantalkin, A., Finkelstein, I., and Piasetzky, E. 2011: 'Iron Age Mediterranean Chronology: a rejoinder', Radiocarbon 53: 179-98.

Faulkner, A. 2008. The Homeric Hymn to Aphrodite. Oxford: Oxford University Press.

Garbini, G. 1978. 'Un'iscrizione aramaica a Ischia', La Parola del Passato 179: 143-50.

Heubeck, A. 1986. 'Die Würzburger Alphabettafel', Würzburger Jahrbücher für die Altertumswissenschaft 12: 7-20.

Heurgon, J. 1980. ‘À propos de l'inscription “tyrrhénienne” de Lemnos', CRAI 1980, 578-600. 
— 1982. 'À propos de l'inscription “tyrrhénienne” de Lemnos', PP 37: 189-92.

Holloway, R. R., and Holloway, N. D. 1993. 'Where did the Greeks learn to write?', Archaeological News 18: 1-5.

Isserlin, B. S. J. 1982. 'The earliest alphabetic writing', in J. Boardman, ed., The Cambridge Ancient History ${ }^{2}$ III.1. Cambridge: Cambridge University Press, 794-818.

Janko, R. 1982. Homer, Hesiod and the Hymns: diachronic development in epic diction. Cambridge: Cambridge University Press.

— 1992. The Iliad: a commentary. IV: Books 13-16. Cambridge: Cambridge University Press.

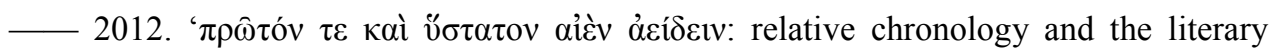
history of the Greek epos', in Andersen and Haug 2012: 20-43.

Jeffery, L. H., 1990 [1961]. The local scripts of Archaic Greece. Revised edition by A. W. Johnston. Oxford.

—. 1976. Archaic Greece. The City-States c.700-500 B.C. London: Methuen.

—. 1979. 'The inscriptions', in Popham, M. R., and Sackett, L .H., with Themelis, P. G. Lefkandi I: the Iron Age Settlement, the Cemeteries. London: British School at Athens, 89-93.

- 1982. 'Greek alphabetic writing', in J. Boardman, ed. Cambridge Ancient History ${ }^{2}$ III.1. Cambridge: Cambridge University Press, 819-33.

Johnston, A. W. 1990. Supplement to Jeffery, L. H., 1990 [1961]. The Local Scripts of Archaic Greece. Oxford.

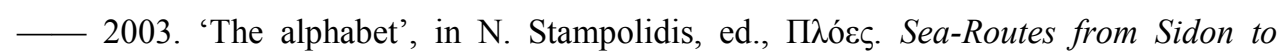
Huelva: interconnections in the mediterranean, Athens: University of Crete, 263-76.

_ 'Amphoras have mouths: do they speak?', in Tzifopoulos and Clay forthcoming.

Johnston, A. W., and Andriomenou, A. 1989. 'A Geometric Graffito from Eretria', BSA 84: 217-20.

Kenzelmann Pfyffer, A., Theurillat, T., and Verdan, S. 2005. 'Graffiti d'époque géométrique provenant du sanctuaire d'Apollon Daphnéphoros à Erétrie', ZPE 151: 51-83.

Kochavi, M. 1977. 'An ostracon of the Period of the Judges from 'Izbet Sartah', Tel Aviv 4:1-13.

Kotsonas, A. et al. 'Inscribed transport amphorae at Methone: provenance and content', in Tzifopoulos and Clay forthcoming.

Lane Fox, R. 2008. Travelling Heroes in the epic age of Homer. London: Allen Lane.

Langdon, M. K. 2005. 'A new Greek abecedarium', Kadmos 44: 175-82.

Larfeld, W. 1914. Griechische Epigraphik, ed. 3. Munich: Beck.

Lejeune, M. 1969. 'Discussions sur l'alphabet phrygien', SMEA 10: 19-47. 1972. Phonétique historique du mycénien et du grec ancien. Paris: Klincksieck. 
Lemaire, A. 2008. 'The spread of alphabetic scripts (c.1700-500 BCE)', Diogenes 218: 44-57.

Lipiński, E. 2004. Itineraria Phoenicia. Studia Phoenicia 18. Leuven: Peeters.

Liver, J. 1953. 'The chronology of Tyre at the beginning of the First Millennium BC', Israel Exploration Journal 3: 119-20.

Malkin, I. 1998. The Returns of Odysseus: colonization and ethnicity. Berkeley, Los Angeles and London: University of California Press.

Malzahn, M. 1999. 'Das Lemnische Alphabet: eine eigenständige Entwicklung', Studi Etruschi 53: 259-79.

Manning, S., Kromer, B., Kuniholm, P. I., and Newton, M. 2001. "Anatolian tree rings and a new chronology for the East Mediterranean Bronze-Iron Ages," Science 294.5551: 2532-5.

— 2003. "Confirmation of near-absolute dating of east Mediterranean Bronze-Iron dendrochronology," Antiquity 77: 295.

Méndez Dosuna, J. 'Were there Panhellenes at Methone?', in Tzifopoulos and Clay forthcoming.

Nijboer, A. J., and van der Plicht, J. 2008. 'The Iron Age in the Mediterranean: recent radiocarbon research at the University of Groningen', in D. Brandherm and M. Trachsel, A New Dawn for the Dark Age? Shifting Paradigms in Mediterranean Iron Age Chronology, British Archaeological Reports no. 1871: 103-18.

Nijboer, A. J., van der Plicht, J., Bietti Sestieri, A.M., and De Santis, A. 2000. 'A High Chronology for the Early Iron Age in Central Italy', Palaeohistoria 41-2: 163-76.

Nijboer, A. J. 2005. 'La cronologia assoluta dell'età di Ferro nel Mediterraneo, dibattito sui metodi e sui risultati', in Bartoloni and Delpino 2004, 527-56.

Oikonomaki, N. 'Local "literacies" in the making', in Tzifopoulos and Clay forthcoming.

Olson, S. D. 2012. The Homeric Hymn to Aphrodite and related texts. Berlin and Boston: De Gruyter.

Parker, V. 1997. Untersuchungen zum Lelantischen Krieg, Stuttgart: Franz Steiner.

Parry, M. 1971. The making of Homeric verse. Edited by A. Parry. Oxford: Clarendon Press.

Peñuela, J. M. 1953: 'La Inscripción Asiria IM 55644 y la Cronología de los Reyes de Tiro', Sefarad 13 (Part 1): 219-28.

Peruzzi, E. 1992. 'Cultura greca a Gabii nel secolo VIII', La Parola del Passato 47: 115-26.

Powell, B. B. 1991. Homer and the origin of the Greek alphabet. Cambridge: Cambridge University Press.

Prosdocimi, A. 1990. 'Insegnamento e apprendimento della scrittura nell'Italia antica, 5. Alfabeto teorico e alfabeto pratico. La sequenzialità', in M. Pandolfini and A. Prosdocimi (edd.), Alfabetari e insegnamento della scrittura in Etruria e nell'Italia antica. Florence: Olschki, 221-30. 
Ridgway, D. R. 1996. 'Greek Letters at Osteria dell'Osa', Opuscula Romana 20: 87-97.

Rix, H. 2004. 'Etruscan', in R.G. Woodard, Cambridge Encyclopaedia of the World's ancient languages, Cambridge: Cambridge University Press, 943-66.

Rose, C. B., Darbyshire, G., DeVries, K. et al. (edd.). 2011. The new chronology of Iron Age Gordion. Philadelphia: University of Pennsylvania Museum of Archaeology and Anthropology.

Ruijgh, C. J. 1995. 'D’Homère aux origines proto-mycéniennes de la tradition épique', in J. P. Crielaard (ed.), Homeric Questions. Amsterdam: Gieben, 1-96.

—. 1997. 'La Date de la création de l'alphabet grec et celle de l'épopée homérique', BO 54: 533-603.

—. 1998. 'Sur La Date de la création de l'alphabet grec', Mnemosyne 51: 658-87.

- 2011. 'Mycenaean and Homeric language', in Y. Duhoux and A. M. Davies (edd.), A Companion to Linear B: Volume 2. Louvain-la-Neuve: Peeters, ii. 253-98.

Sass, B. 2005. The alphabet at the turn of the millennium : the West Semitic alphabet ca. 1150-850 BCE: the antiquity of the Arabian, Greek and Phrygian alphabets. Tel-Aviv: Institute of Archaeology of Tel Aviv University.

Schmitz, P. C. 2009. 'Phoenician KRNTRYŠ, Archaic Greek *KOPYNHTHPIO $\Sigma$, and the Storm God of Aleppo', Kleine Untersuchungen zur Sprache des Alten Testaments und seiner Umwelt 9: 119-60.

Scott, D. A., Woodard, R. D., McCarter, P. K., Zuckerman, B., and Lindberg, M. 2005. 'Greek alphabet (MS 108)', in R. Pintaudi, Papyri graecae Schøyen (PSchøyen 1). Papyrologica Florentina 35. Florence: Gonnelli, 149-60.

Segert, S. 1977. 'The origin of the Greek alphabet. Preliminary observations concerning an on-going research project', Archaeology at UCLA 1: fasc. 11.

Sherratt, E. S. 2003. 'Visible writing: questions of script and identity in Early Iron Age Greece and Cyprus', Oxford Journal of Archaeology 22: 225-42.

Skelton, C. 'Thoughts on the initial aspiration of AKE $\Sigma$ AN $\triangle$ PO', in Tzifopoulos and Clay forthcoming.

Tandy, D. W. 2000. Warriors into Traders: the Power of the Market in Early Greece. Berkeley and Los Angeles.

Theurillat, T., 2007, 'Early Iron Age graffiti from the Sanctuary of Apollo at Eretria', in A.Mazarakis Ainian, Oropos and Euboea in the Early Iron Age, Volos: University of Thessaly: 331-44.

Toffolo, M. B. et al. 2013. 'Towards an absolute chronology for the Aegean Iron Age: new radiocarbon dates from Lefkandi, Kalapodi and Corinth', PloS ONE 8/12: e 83117.

Tzifopoulos, Y. Z., and Clay, J. S. Panhellenes at Methone: graphê in Late Geometric and Protoarchaic Methone, Macedonia. Forthcoming. 
van der Plicht, J., Bruins, H.J., and Nijboer, A.J. 2009: 'The Iron Age around the Mediterranean: a High Chronology perspective from the Groningen Radiocarbon Database', Radiocarbon 51: 213-42.

Wackernagel, J. 1916. Sprachliche Untersuchungen zu Homer. Göttingen: Vandenhoeck and Ruprecht.

Walker, K. G. 2004. Archaic Eretria: a political and social history from the earliest times to 490 BC. London and New York: Routledge.

Wallace, R. 2008. Zikh Rasna: a manual of the Etruscan language and inscriptions. Ann Arbor and New York: Beech Stave.

- 2011. 'The Latin alphabet and orthography', in J. Clackson, ed., A Companion to the Latin language, Chichester: 9-28.

Wathelet, P. 1981. 'La Langue homérique et le rayonnement littéraire de l'Eubée', AC 50: 819-33.

Węcowski, M. 'Hakesandros, Tataie and the "cup of Nestor"', in Tzifopoulos and Clay forthcoming.

Whisenant, J. N. 2008. Writing, literacy, and textual transmission: the production of literary documents in Iron Age Judah and the composition of the Hebrew Bible. Ann Arbor: University of Michigan Press.

West, M. L. 1978. Hesiod: Works and Days. Oxford: Oxford University Press.

— 1988. 'The rise of the Greek epic', JHS 108: 151-72.

— 2012. 'Towards a chronology of early Greek epic', in Andersen and Haug 2012, 224-41.

Woodard, R. D. 1997. Greek writing from Knossos to Homer. New York and Oxford: Oxford University Press.

Young, R. S. 1969. 'Old Phrygian inscriptions from Gordion: toward a history of the Phrygian alphabet', Hesperia 38: 252-96. 